\title{
The Annexin Code : revealing cardiovascular disease
}

Citation for published version (APA):

Kietselaer, B. L. J. H. (2008). The Annexin Code : revealing cardiovascular disease. [Doctoral Thesis, Maastricht University]. Datawyse / Universitaire Pers Maastricht. https://doi.org/10.26481/dis.20080619bk

Document status and date:

Published: 01/01/2008

DOI:

10.26481/dis.20080619bk

Document Version:

Publisher's PDF, also known as Version of record

\section{Please check the document version of this publication:}

- A submitted manuscript is the version of the article upon submission and before peer-review. There can be important differences between the submitted version and the official published version of record.

People interested in the research are advised to contact the author for the final version of the publication, or visit the DOI to the publisher's website.

- The final author version and the galley proof are versions of the publication after peer review.

- The final published version features the final layout of the paper including the volume, issue and page numbers.

Link to publication

\footnotetext{
General rights rights.

- You may freely distribute the URL identifying the publication in the public portal. please follow below link for the End User Agreement:

www.umlib.nl/taverne-license

Take down policy

If you believe that this document breaches copyright please contact us at:

repository@maastrichtuniversity.nl

providing details and we will investigate your claim.
}

Copyright and moral rights for the publications made accessible in the public portal are retained by the authors and/or other copyright owners and it is a condition of accessing publications that users recognise and abide by the legal requirements associated with these

- Users may download and print one copy of any publication from the public portal for the purpose of private study or research.

- You may not further distribute the material or use it for any profit-making activity or commercial gain

If the publication is distributed under the terms of Article $25 \mathrm{fa}$ of the Dutch Copyright Act, indicated by the "Taverne" license above, 
The Annexin Code 
ISBN 9789052787275

Universitaire Pers Maastricht

(C) Copyright BLJH Kietselaer, Maastricht 2008

Productie en druk: Datawyse Maastricht 


\title{
The Annexin Code Revealing Cardiovascular Disease
}

\author{
PROEFSCHRIFT
}

ter verkrijging van de graad van doctor aan de Universiteit Maastricht, op gezag van de Rector Magnificus, prof. mr. G.P.M.F. Mols, volgens het besluit van het College van Decanen, in het openbaar te verdedigen op donderdag 19 juni 2008 om 12.00 uur

door

Bas L.J.H. Kietselaer

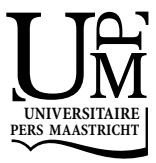




\section{Promotor}

Prof. dr. H.J.G.M. Crijns

\section{Copromotor}

Dr. L. Hofstra

\section{Beoordelingscommissie}

Prof. dr. J.M.A. van Engelshoven (voorzitter)

Dr. S.R.B. Heymans

Prof. dr. J.G. Maessen

Prof. dr. K. Nicolay (Technische Universiteit, Eindhoven)

Dr. J.A. Post (Universiteit Utrecht, Utrecht)

Prof. dr. ir. T. Van der Steen (Erasmus Medisch Centrum, Rotterdam)

This study was performed at the University Hospital of Maastricht (azM). Financial support by the Netherlands Heart Foundation and the Wynand Pon Foundation is gratefully acknowledged.

Financial support for publication of this thesis was given by RESCAR, PharmaTarget, Pfizer, Merck Sharp \& Dohme, Astra Zeneca and Schering Plough. 
Aan Isa en Marieke 


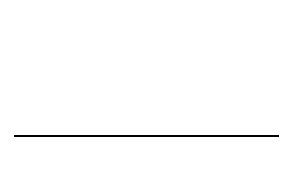




\section{Inhoudsopgave}

Chapter 1 The Annexin Code: Revealing Cardiovascular Disease $\quad 9$

Chapter 2 Non-invasive Detection of Programmed Cell Loss with 33

${ }^{99 \mathrm{~m}}$ Tc-labeled Annexin A5 in Heart Failure

Chapter 3 Molecular Imaging of Apoptosis and Inflammation for

Detection of Infective Endocarditis

Chapter 4 Non-invasive detection of plaque instability using radiolabeled Annexin-A5 in patients with atherosclerotic carotid artery disease

Chapter 5 The diagnosis of intracardiac masses: absence of Annexin A5 uptake indicates favorable prognosis

$\begin{array}{lll}\text { Chapter } 6 & \text { General discussion } & 71\end{array}$

$\begin{array}{lll}\text { Chapter } 7 & \text { Summary } & 81\end{array}$

$\begin{array}{lll}\text { Chapter } 8 & \text { Nederlandstalige samenvatting } & 85\end{array}$

$\begin{array}{ll}\text { Full color figures } & 89\end{array}$

$\begin{array}{ll}\text { Dankwoord } & 97\end{array}$

$\begin{array}{ll}\text { Curriculum vitae } & 101\end{array}$

$\begin{array}{ll}\text { List of publications } & 105\end{array}$ 


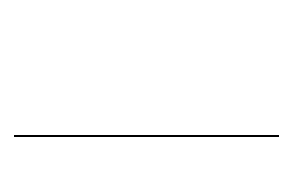




\section{CHAPTER 1}

\section{The Annexin Code: Revealing Cardiovascular Disease}

Published in different format in:

Kietselaer BLJH, Hofstra L, Dumont EA, Reutelingsperger CPM, Heidendal GAK. The role of labeled Annexin A5 in imaging of programmed cell death. From animal to clinical imaging. Q J Nucl Med 2003'.

Kietselaer BLJH, Reutelingsperger CPM, Hofstra L. Molecular Imaging of Programmed Cell Death; from basic mechanisms to clinical applications. In: Al-Rubeai $M$, Fussenegger $M$, eds. Cell Engineering: Apoptosis. Vol. 4. Dordrecht: Kluwer Publishers, $2004^{2}$.

Hofstra L, Reutelingsperger CPM, Kietselaer BLJH, Narula J, Strauss HW. Noninvasive detection of Cell Death in Myocardial Disorders. In: Zaret BL, Beller GA, eds. Clinical Nuclear Cardiology. Philadelphia, Pennsylvania: Elsevier Mosby, $2005^{3}$.

Boersma HH, Kietselaer BLJH, Stolk LM, et al. Past, present, and future of annexin A5: from protein discovery to clinical applications. J Nucl Med $2005^{4}$. 
10 CHAPTER 1 
Cardiovascular disease is the main cause of mortality and morbidity in developed countries worldwide. Despite advances in clinical medicine, cardiovascular disease is responsible for 38.5 percent of all deaths in the United States, or one death every 34 seconds. Furthermore, cardiovascular disease has claimed the lives of more females than males since 1984. About 65 million Americans suffer from one or more forms of cardiovascular disease, 13.2 million of which have coronary artery disease and 5 million suffer from congestive heart failure. In the Netherlands, approximately 675,000 patients suffer from coronary artery disease (CAD). In 2004 90,000 patients were admitted for coronary heart disease. Furthermore, 179,000 patients suffer from heart failure and 27,100 patients suffer from stroke each year ${ }^{5}$. In addition, obesity, diabetes are commonplace among western countries, ensuring an increase in cases and extent of cardiovascular disease. The United States alone have spent over 360 billion USD treating cardiovascular disease $^{6}$. In the Netherlands, CAD is placed among the top 5 of most expensive illnesses ${ }^{5}$. Diagnosis of cardiovascular disease can be done through a large array of technologies such as computer tomography (CT), magnetic resonance imaging (MRI), angiography, echography and electrocardiography (ECG). These technologies allow us to visualize the anatomy of the problem to great detail. They offer insight into the extent of damage that has been sustained, for instance due to atherosclerosis or infarction. However, these technologies only provide limited biological information about the patient's disease, and so can only inform us about the late, anatomical changes that have taken place in the patient.

Recent studies have shown that myocardial infarction does not occur often due to progressive luminal stenosis. Instead, underlying vascular pathology such as inflammation, macrophage activation and apoptosis lead to formation of unstable plaques with a large lipid core, thin fibrous cap and extensive cytokine activation. Such unstable plaques are prone to rupture and formation of an occlusive thrombus. Unfortunately, we are unable to identify patients with impeding acute myocardial infarction (AMI) or stroke. Knowledge of molecular changes preceding such events may present opportunity for early detection and intervention in these patients.

A similar diagnostic problem occurs in diagnosing and treating patients at risk for developing congestive heart failure (CHF). As most patients survive their first acute cardiovascular event, the incidence of patients with damaged hearts increases. Current imaging technology provides excellent insight into ventricular systolic and diastolic function. However, we lack the ability to discriminate patients that will develop CHF from patients that will recover from the primary event. Animal testing has led to profound insight into neurohumoral mechanisms underlying CHF, and augmenting neurohumoral activation improves complaints and prognosis of patients. Using 
animal models, understanding of effects of multiple mediators on cardiac function has improved greatly in recent years. Despite obvious gain in understanding and treating $\mathrm{CHF}$, clinicians are unable to predict patients at risk for adverse left ventricular remodeling. Again, knowledge of the underlying biological processes could enable early detection and prevention.

Unknown intracardiac masses present a diagnostic problem. Intracardiac masses are much more infrequent than CAD but new imaging techniques are also needed here. In addition, proof of concept of new imaging techniques may be obtained in these patients. Classical imaging modalities can visualize size, shape, location and haemodynamic consequences in great detail, but are unable to inform us about the nature of the mass ${ }^{7}$. Intracardiac masses comprise tumors, vegetations and thrombi. Subsets of these masses are associated with unfavorable outcome, such as malignant tumor, infective endocarditis and fresh thrombus. Obtaining biological information in addition to anatomical diagnosis may therefore have clinical implications.

\section{MOLECULAR IMAGING IN GENERAL}

Molecular imaging is a swiftly developing technique that aims to visualize the biology and physiology of disease in the organisms in a repetitive and non-invasive way ${ }^{8}$. The limited spatial resolution of conventional imaging techniques such as CT of MRI does not allow visualization of anatomic consequences of disease below a size of 0.5 to $1 \mathrm{~cm}$. This limitation of spatial resolution precludes detection of early stages of disease. In addition, once an anatomical consequence of a disease has been diagnosed, conventional imaging does not provide us with biological or molecular information about the anatomical abnormality ${ }^{9}$.

The challenges that face successful molecular imaging are similar to drug targeting. One needs to find a target molecule that accumulates in the tissue of interest in a high enough dose to be visualized but without losing target properties after labeling with a marker, such as fluorescent probes, MRI or CT contrast, or radioactive agents. Finding the correct molecule for imaging will be driven by understanding of the biology of the underlying disease. By imaging biological changes preceding disease (see figure 1), clinicians may arrive earlier at the correct diagnosis. This opens the way for early, aggressive, targeted treatment. Furthermore, it can provide information on lesions not suitable for biopsy taking. Thirdly, it may serve as a surrogate endpoint when evaluating success of novel drugs. Finally, molecular imaging could become a valuable tool for obtaining proof of concept for a given labeled target molecule in terms of targeting properties 
and efficacy. In conclusion, one could state that molecular imaging could not only serve as a novel tool for the early detection of cardiovascular disease, but also may provide the key to new drug targeting options.

Molecular imaging Conventional imaging

Early detection

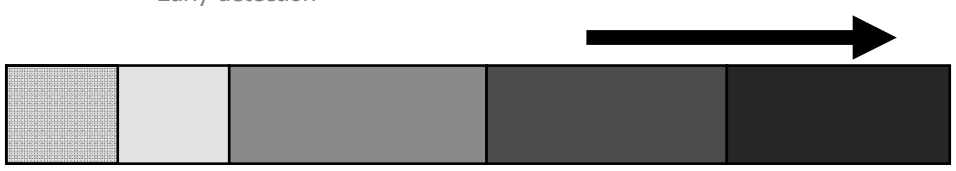

Predisease state Beginning of disease Anatomical changes Physiological changes

Figure 1:

Molecular imaging versus anatomical imaging. Molecular imaging detects changes on a molecular level, preceding the changes in anatomy. Potentially, detecting disease in an early stage may aid clinicians and patients, enabling early treatment. In addition, scans can be easily repeated studying effect of treatment. Furthermore, information on lesions not suitable for biopsy taking can be acquired. For cull color image see page 91

As we will demonstrate below, phosphatidylserine (PS) expression is an attractive target for imaging biological processes underlying cardiovascular disease. The most well studied form of PS exposure linked to cardiovascular disease is PS exposure associated with apoptosis, or programmed cell death. However, PS exposure is not solely associated with apoptosis, as it can be seen in activated macrophages and lymphocytes, as well as in activated platelets.

PS expression can therefore be found in unstable plaques due to local inflammation and apoptosis. In addition, numerous studies have indicated that apoptosis is an important underlying mechanism in the development of CHF. We therefore hypothesize that imaging of PS exposure is helpful in gaining insight into molecular events preceding clinical cardiovascular disease, and could therefore have additional diagnostic value.

\section{NORMAL PHOSPHATIDYLSERINE DISTRIBUTION IN CELL MEMBRANES}

The phospholipid bilayer of the plasma membrane can be seen as a pair of parallel sheets providing a matrix for supporting membrane proteins. However, an increasing body of evidence supports an important role for the composition of this bilayer. The bilayer surrounding cells is asymmetric $^{10}$, and choline-containing lipids, phosphatidylcholine (PC) and sphingomyelin (SM) are primarily found on the outer membrane of normal cells. The cytosolic, inner membrane of cells is mostly made up of amine contain- 
ing phospholipids, such as phosphatidylethanolamine (PE), phosphatidylserine (PS). Some minor phospholipids like phosphatic acid (PA), phosphatidylinositol (PI) and phosphatidylinosotol-monophosphate (PIP) are also preferentially located in the cytosolic side of the cell membrane. The synthesis of these lipids inherently causes asymmetry, as the enzymes responsible for synthesis of lipids are typically located in the cytosol of cells. The major glycophospholipids, PS, PC, PE, and PI are generated in the endoplasmatic reticulum $(E R)^{11}$, and are transported by a lipid transporter across the ER membrane ${ }^{12,13}$. This should cause even distribution of lipids across the ER membrane. However, in normal cells the plasma membrane is asymmetric. Consequently there should be a process controlling distribution of phospholipids across the plasma membrane, producing asymmetry. Causing asymmetry is an active process, requiring input of energy for development of this asymmetry. Both outward and inward lipid transporters are ATP dependent.

The makeup of the plasma membrane prevents spontaneous redistribution (also termend "flip-flop") of phospholipids, and half time for such a flipflop is several hours to days and depends on the nature of the lipid and the membrane ${ }^{14}$. Therefore spontaneous flip-flop has very limited impact. The most important contributors to membrane asymmetry are proteins that catalyze the movement of lipids across the membrane. Inward transporters have been termed flippases (or translocases), and outward transporters floppases, of which several have been characterized. In addition, there is a category of aspecific, bi-directional lipid transporters, the scramblases. Activation of scramblases is not ATP dependent, but is initiated by rising $\mathrm{Ca}^{2+}$ concentration inside a cell. Flippase, also termed $\mathrm{Mg}^{2+}$ ATPase, is highly selective for $\mathrm{PS}^{15}$. It is ubiquitously distributed in erythrocytres ${ }^{16}$, but is has also been observed in platelets ${ }^{17}$, lymphocytes ${ }^{18}$, aortic endothelial cells $^{19}$, fibroblasts $^{20}$ and hepatocytes ${ }^{21}$. Activity is present at both the basal and the apical side of epithelial cells ${ }^{22}$. It seems likely that this transporter is essential for any membrane in which PS should only be present on the cytosolic side. The identity of this flippase remains elusive, although some candidates have been identified ${ }^{23}$. Floppases have been identified for cholesterol $^{24}, \mathrm{PC}$ and short chain phospholipids ${ }^{25}$. The only floppase that has been described for PS is $A B C$ transporter ABCA1 (ABC1), which is responsible for PS mediated engulfment by macrophages in c. elengans ${ }^{26}$. It is unclear how this molecule is activated, but it is not involved in maintenance of membrane asymmetry. Like the flippases, floppases are ATP dependent. In contrast to these molecules, scramblases are aspecific in their substrate, and serve to abolish membrane asymmetry. 


\section{PS EXPOSURE IN APOPTOSIS}

The most well described cause of PS exposure on the outer membrane is that linked to apoptosis ${ }^{27}$. First described by Fadok et al, PS exposure during apoptosis has also been described in chick and Drosophila ${ }^{28}$, indicating that lipid asymmetry is a feature of cells of vertebrate and invertebrate animals. The common ancestor of both lived somewhere in the Precambrian, making this process about 600 million years old ${ }^{29}$. During programmed cell death the translocases are blocked, probably due to increased concentration of $\mathrm{Ca}^{2+}$ and decreased levels of ATP. It has been proposed that floppase and scramblase are activated as a consequence of caspase 3 mediated cleavage of protein kinase C- $\delta^{30}$. However, caspase inhibition does not prevent PS exposure in in vitro models of apoptotis ${ }^{30,31}$ and caspase independent apoptosis is associated with PS exposure ${ }^{31}$, pointing to alternate mechanisms of scramblase activation. Some authors have suggested a role for APAF in activation of scramblase ${ }^{29,32}$.

\section{NON-APOPTOTIC PS EXPOSURE}

Besides being a marker for apoptosis, rapid PS exposure is seen in platelets stimulated by thrombin and collagen, due to scramblase activation and flippase inhibition ${ }^{33,34}$. Exposed PS is essential for assembly of active prothrombinase $^{35}$, and plays a role in activation of prothrombin ${ }^{36}$. Detection of PS exposure has been used to detect fresh cloth in porcine left atrial thrombus ${ }^{37}$. Moreover, PS exposure has been observed in cell-cell connections $^{38}$. Finally, Callahan et al. describe that macrophages express PS on their surface when activated. Molecules that bind to PS can inhibit engulfment by macrophages, but more interestingly, these authors find that Annexin A5 addition to activated macrophages also inhibits engulfment of apoptotic cells or PS coated vesicles by macrophages ${ }^{39}$.

\section{CONSEQUENCE OF PS EXPOSURE}

PS exposure is not the only, but by far the best characterized "eat me" signal for cells undergoing programmed cell death. Water-soluble PS can inhibit engulfment of apoptosis, pointing to the fact that PS exposure is not only a marker for apoptosis, but it also plays an important role in removal of apoptotic cells ${ }^{27}$. Fadok and co-workers have identified a protein that specifically binds PS and is required for phagocytosis ${ }^{40}$. In addition, scavenger receptors such as $\mathrm{CD} 36^{41} \mathrm{CD} 68$ and $\mathrm{CD} 91^{42}$ recognize externalized $\mathrm{PS}^{43}$. Recently, it has been shown that PS exposure alone is not enough for engulfment by macrophages. Bridging molecules like milk fat globuline E8 
(MFG-E8) $^{44}$ are necessary for macrophages to recognize and confirm PS exposure, so it can engulf apoptotic cells. Indeed, mice lacking the MFG-E8 gene develop auto-immune disease, a consequence of deficient clearance of apoptotic cells ${ }^{45}$. Such a model has been termed "tether and tickle", in the sense that PS expressing cells are recognized by macrophages in absence of MFG-E8, but are not engulfed. Only when MFG-E8 is present, cytoskeletal rearrangement of the macrophage is achieved and the apoptotic cell can be engulfed ${ }^{46}$. PS expression serves as a powerful signal for macrophages to remove apoptotic cells.

\section{APOPTOSIS IN GENERAL}

Apoptosis, or programmed cell death is the process multi cellular organisms use to maintain tissue homeostasis. In addition, programmed cell death plays an important role in embryologic development. More importantly, imbalance of apoptosis and cell division can lead to disease (Figure 2).

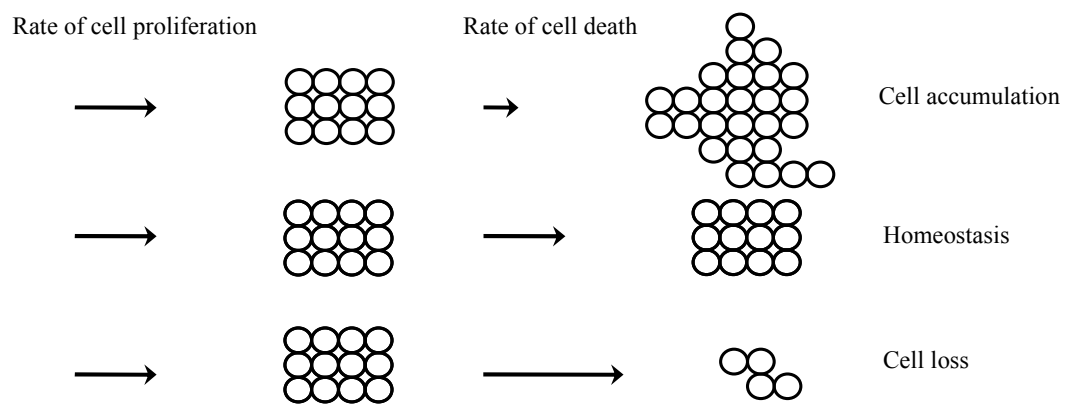

Figure 2:

Balance of cell division and cell loss. In general it is believed that apoptosis is a mechanism used by organisms to maintain stable cell numbers. In the middle panel the rate of cell proliferation is equal to the rate of cell death, providing tissue homeostasis. Disturbance of this delicate balance often leads to diseases of pathological cell accumulation such as seen in cancer (upper panel). The lower panel shows diseases involving pathological cell loss such as neuro-degenerative diseases of myocardial infarction.

Targeted deletion of cells shapes organs, cuts out fingers and shapes the heart and thus sculpts the embryo. Both the immune system and the nervous system are shaped through apoptosis: cells that do not form integral connections with other cells are pushed towards cell death. In adult man, about 10 billion cells die daily just to counter amount of cells gained by multiplication, or mitosis. As such, programmed cell death is an integral part of development and life of any organism. Interestingly, the 
process of apoptosis is conserved from worm to man, allowing rapid translation of insights gained in animal models into clinical practice. The first description of apoptosis was done by Walther Flemming, who called it "chromatolysis" in 1885 describing non-necrotic ovarian cells wherein the nuclei were breaking up. Months later Franz Nissen reported similar cells in lactating mammary glands. In 1910 the process was again described by a german anatomist, Ludwig Graper, and in 1967 Frans Wackers used the term "bionecrosis" to describe similar cells in mammary glands ${ }^{47}$. But major interest in the process only came about after it's description by Wyllie and $\mathrm{Kerr}^{48}$, who introduced the term "apoptosis". To date approximately 85,000 publications deal with the process of apoptosis (source: national library of science). Consequently, most genes and proteins regulating apoptosis have been identified in the last 20 years. Apoptosis concerns so many parts of life that it has to be tightly regulated. A central role is played by enzymes termed the caspases (cystein aspartate specific proteases), which cause many of the morphological features associated with programmed cell death such as chromatin condensation, dissolution of the nuclear membrane, nuclear shrinkage and formation of apoptotic bodies. These apoptotic bodies are then cleared by adjacent cells and professional phagocytes ${ }^{48-50}$. In addition, activation of caspase 3 causes one of the final steps in programmed cell death, that of fragmentation of cellular DNA, through activating a specific endonuclease. Classically, two pathways are defined which can lead to activation of the caspases, the intrinsic and extrinsic pathway. Both pathways react to different stimuli, which can cause the cell to initiate its cell death program. The intrinsic pathway is activated when external signals, such as binding of Fas ligand or Tumor Necrosis Factor (TNF) to its receptor. These receptors are also termed death receptors. The binding of either Fas ligand or TNF to death receptors then causes the activation of caspase 8, which in its turn activates a cascade of caspases. This finally leads to the demise of the cell and clearance of the cell remnants by macrophages. The intrinsic pathway is activated through direct damage to the cell, such as radiation, serum starvation or reactive oxygen species. This in term leads to release of different factors from the mitochondrion, such as Cytochrome C, apaf-1 and apoptosis inducing factor (AIF). Cytochrome C and apaf- 1 react with caspase 9 to form the apoptosome, which trigger further downstream apoptotic events. Both pathways converge at the activation of caspase 3. However, as research progresses, evidence of cross talk between these pathways and caspase-independent cell death emerges, as more regulatory mechanisms are discovered ${ }^{51}$. Also, the classical division between apoptosis and necrosis has been abandoned. Rather, a model has been suggested with a gliding scale between classic, caspase mediated apoptosis, and accidental necrosis or cell lysis. The intermediate steps are apoptosis like programmed cell death, the "caspase independent cell death" and necrosis-like programmed cell death, which seems to be mostly 
mitochondrially mediated ${ }^{52}$. Except for accidental necrosis and cell lysis, all these forms of cell death can be influenced by administration of cell death inhibitors or promoters, and thus they are modifiable processes. As already stated, apoptosis plays an important part in life and development. Consequently, deregulation of programmed cell death can cause severe dysfunction of the organism. In embryological development, not deleting unwanted cells may lead to congenital malformations. In addition, apoptosis is important in many other diseases. A relative low amount of cell death compared to the mount of cell division may lead to diseases of cell accumulation as is observed in tumor development or autoimmune disease. In contrast, a relatively high amount of cell death compared to the amount of cell division can lead to diseases of cell loss. This type of disease is seen in myocardial or cerebral infarction, heart failure, myocarditis and transplant rejection.

\section{APOPTOSIS IN CARDIOVASCULAR DISEASE}

Organs that have limited or no regenerative capacities such as the heart and the brains may permanently suffer from loss of function due to excess apoptosis. In addition, intervention in the apoptotic program can decrease the amount of tissue loss, and preserve organ function. Myocardial apoptosis has been associated with end stage congestive heart failure ${ }^{53,54}$, arrythmogenic right ventricular dysplasia ${ }^{55}$ and myocardial infarction ${ }^{53,56}$. In addition, cardiomyocyte apoptosis has been detected in animal models of ischaemia/ reperfusion ${ }^{57}$ and heart failure ${ }^{58,59}$. Cardiac myocytes have a high energy consumption and $30 \%$ of the volume of a cardiomyocyte is taken up by mitochondria. Upon ischaemia and reperfusion, mitochondria release pro-apoptotic factors such as Cytochrome $\mathrm{C}^{60}$ and reactive oxygen species $(\mathrm{ROS})^{61}$, which may in turn activate downstream caspases. In addition proteolitically cleaved caspases 2, 3 and 7 have also been detected in ischaemia/ reperfusion models, suggesting a role for receptor-mediated cell death ${ }^{62}$. Thirdly, calcium overload plays an important role in cardiomyocyte apoptosis following ischaemia/ reperfusion. It has been shown that calcium influx inhibitors can reduce the amount of damage following ischaemia/ reperfusion ${ }^{63}$. Calcium overload can lead to the permeability transition pore (PTP), which causes release of Cytochrome $\mathrm{C}$ and activation of downstream caspases, activation of endonucleases and proteases such as calpain. Calpain in turn may activate pro-apoptotic factors such as Bid. All these mechanisms may provide possible targets for prevention of loss of contractile mass. Cardiomyocyte apoptosis usually occurs within the first 24 hours after the acute insult, and is subsequently followed by myocyte necrosis ${ }^{64,65}$. Heart failure can be caused by subsequent inadequate remodeling, or may occur due to genetic defects, neurohumoral stress or pres- 
sure overload. The amount of apoptosis is much less as compared to acute ischaemic events. However, one could hypothesize that continuous lowgrade apoptosis can produce similar or even more extensive damage than acute ischaemic events. Data concerning timing and duration of apoptosis in heartfailure are lacking. However, several authors have shown activation of parts of the cell death program in animal models of heart failure ${ }^{58,59}$ and human biopsy samples ${ }^{53}$ and explanted hearts ${ }^{54}$. Indeed, tissue sections of explanted hearts from patients with end stage heart failure shows presence of apoptosis ${ }^{54}$ in cardiomyocytes. It has been shown in animal models of heart failure that intervention in apoptotic signaling can reverse cardiac remodeling and increase survival ${ }^{66}$. Regulating cell death could therefore be an important therapeutic target in disease. When novel treatment strategies are tested, cell death needs to be diagnosed, quantified and continuously monitored.

\section{DETECTION OF APOPTOSIS}

Apoptosis was originally identified based on morphological features such as chromatin condensation, dissolution of the nuclear membrane, nuclear shrinkage and formation of apoptotic bodies, which are then cleared by adjacent cells and professional phagocytes ${ }^{48-50}$. DNA fragmentation, the hall-mark of apoptosis, is identified by in situ end-labeling techniques of DNA fragments in the nuclei. These fragmented pieces of DNA can be detected by several techniques. The best known of these involves staining of tissue sections by the terminal deoxynucleotidyl transferase (TdT)mediated dUTP nick end-labeling (TUNEL), in which the free $3^{\prime}-\mathrm{OH}$ termini that occur during DNA fragmentation are labeled and detected ${ }^{67}$. Additionally, antibodies against single stranded DNA can be used for the detection of fragmented DNA. These techniques are not specific for apoptotic cell death, since they also detect DNA cleavage due to environmental DNA damage or DNA repair ${ }^{68}$. DNA fragmentation occurs secondary to the activation of highly specific terminal proteolytic enzymes called caspases. Caspases (cysteïne aspartate-specific proteases) once activated, leads to cleavage of cytoplasmic proteins and activation of DNAses. Since normal cells contain DNA fragmentation factors in their inactive form, the cleavage process can proceed quickly once the caspases are activated. The inhibitor of caspase activated deoxyribonuclease (CAD), termed ICAD, is cleaved during programmed cell death by caspase 3 , resulting in release of $C^{2} D^{69}$. Detection of activated caspase 3 or caspase cleavage products can be performed on tissue sections as well, and thereby provide clues for detection of apoptosis in addition to the morphological features and staining methods. Activated caspases can also be characterized and quantified by a variety of other techniques, including immunoblotting, cleavage of syn- 
thetic substrates, affinity labeling and confocal microscopy ${ }^{70}$. Earlier mediators of apoptosis have also been characterized to address the upstream cascade of apoptosis. Such mediators include demonstration of pro survival signals (such as IAPs XIAPs and Bcl-xl) and signals that drive the cell toward cell death such as ligation of pro-apoptotic death receptors and release of cytochrome $\mathrm{C}$ from mitochondria.

These techniques all require samples of the target tissue. In addition, cells that are stressed may undergo programmed cell death, or as current evidence suggests, the cell death program may be interrupted, or reversed, before the cell dies. As a result, monitoring tissues for cell death should be a dynamic process, where repetitive measurements can be made in the same tissue. Even though immuno-histochemical and/or blotting techniques offer high spatial resolution of the cells, the techniques do not allow the same cells to be followed through the cell death process. In addition, the tissue that is sampled is often a small fraction of the total tissue involved in the process, making it likely that the sample may not represent the true state of the tissue. This can lead to erroneous conclusions or even a false diagnosis. Development of a technology that allows non-invasive monitoring of apoptosis in vivo could therefore be of significant benefit. Ideally, in-vivo monitoring of programmed cell death should be noninvasive, suitable for repeated measurements in the same organism, safe and rapid $^{8}$. Molecular imaging is able to combine insights in molecular biology with state of the art imaging technology.

\section{EMPLOYING LABELED ANNEXIN A5 FOR MOLECULAR IMAGING OF CELL DEATH}

As mentioned previously, during the process of apoptosis the normally asymmetric distribution of phospholipids in the cell membrane lipid bilayer is lost and leads to preferential expression of phosphatedyl serine (PS) on the outer cell membrane. PS is an avid target for a physiologic protein, Annexin A5. This protein can be labeled with iron oxide particles for MR imaging, fluorescent probes for optical imaging or radiotracers for nuclear imaging. The labeled Annexin A5 may traverse from the blood compartment it traverses through the endothelial barrier to enter the extracellular space over several hours. Once in the extracellular space, annexin binds to exteriorized PS; and may remain at the site of interaction for a sufficient time to permit imaging. ${ }^{8}$ In addition to Annexin A5, externalized phosphatidyl serine can be a target for other molecules. Synaptotagmin I, for example, has a $\mathrm{C} 2$ domain that binds to anionic phospholipids exposed on the outer membrane of cells. It has been shown that this molecule can be 
labeled with super paramagnetic ion oxide nanoparticles (SPIOs) ${ }^{71}$ for use as an MRI probe.

Annexin A5 binds to phospholipids in a $\mathrm{Ca}^{2+}$ dependent manner. Some authors propose a model in which $\mathrm{Ca}^{2+}$ causes a change in conformation of the binding site of Annexin A5, which can then bind to the (exposed) phosphatidyl serine. In 1995 this mechanism was used to develop an assay based on the binding of Annexin A5 to apoptotic cells ${ }^{72}$. The affinity assay of Martin et al and van Engelshoven et $\mathrm{al}^{73,74}$ showed that Annexin A5 could be used to detect programmed cell death in vitro. In this assay, Jurkat cells, an immortalized cell line, were stimulated with a potent trigger for apoptosis, Fas ligand. It was then shown that fluorescently labeled Annexin A5 bound to these cells in all phases of the cell death program (Figure 3).
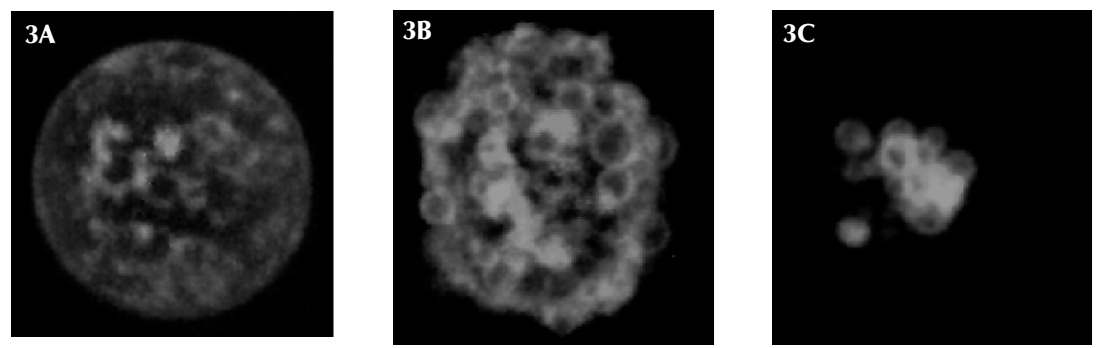

Figure 3:

Annexin A5 binds to cells in all stages of the cell death program. Here, Jurkat cells are stimulated by Fas ligand. In figure $3 A$, the early phase of apoptosis is seen. Already we can observe binding of fluorescent labeled Annexin A5 to the cell membrane. Figure $3 B$ depicts a later stage, in which we see formation of blebs and Annexin A5 binding. Figure $3 C$ is the final stage of apoptosis, the cell remnants. These also bind labeled Annexin A5. For cull color image see page 91. 
This concept also works in the complex environment of the living organism, as several different lines of experiments in our group have shown. Studies on embryonic mice models show detection of developmental apoptosis. Appearance of apoptosis during formation of the digits takes place at stage E13 in the chick embryo. Biotin labeled Annexin A5 was administered prior to sacrifice of the organism. Binding of the labeled Annexin A5 was seen in the interdigital webs ${ }^{38}$, as shown in figure 4, thereby proving the concept that Annexin A5 has a sufficiently long circulating can be used for the detection of apoptosis in the complex environment of a living organism.

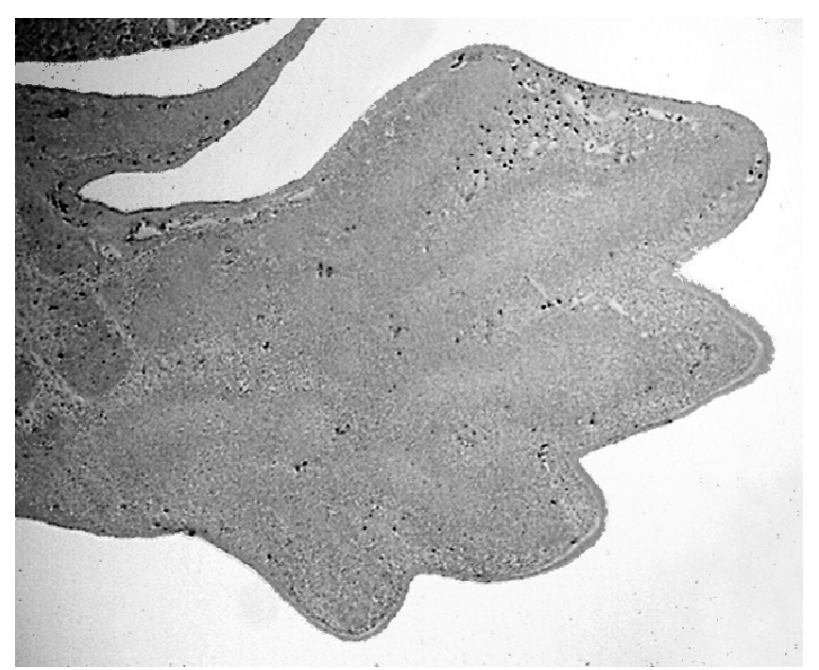

Figure 4:

Paw of a chick embryo at day 13. Binding of labeled Annexin A5 (note brown staining) can de observed in interdigit spaces. For full color image see page 92. 
In addition, prior studies have shown the use of this assay for detection of apoptosis in pathological situations. Mimicking the situation of a myocardial infarction, a mouse model of ischaemia and reperfusion was used. The left anterior descending artery of the heart of a mouse was ligated. Prior to ligation of the artery, labeled Annexin A5 was infused. The ligation of the left anterior descending artery initiates cell death distal to the site of ligation. The animal was sacrificed, and the biotin label attached to Annexin A5 could easily be detected by immuno-histochemical analysis of tissue. Dumont et al. showed this model not detects cell death, but can also evaluate the efficacy of cell death blocking agenst ${ }^{57}$. In addition, in vivo detection of programmed cell death was possible using fluorescently labeled Annexin A5. Detection of Annexin A5 binding to cardiomyocytes was achieved using a microscope equipped with a fluorescent module (Figure 5).
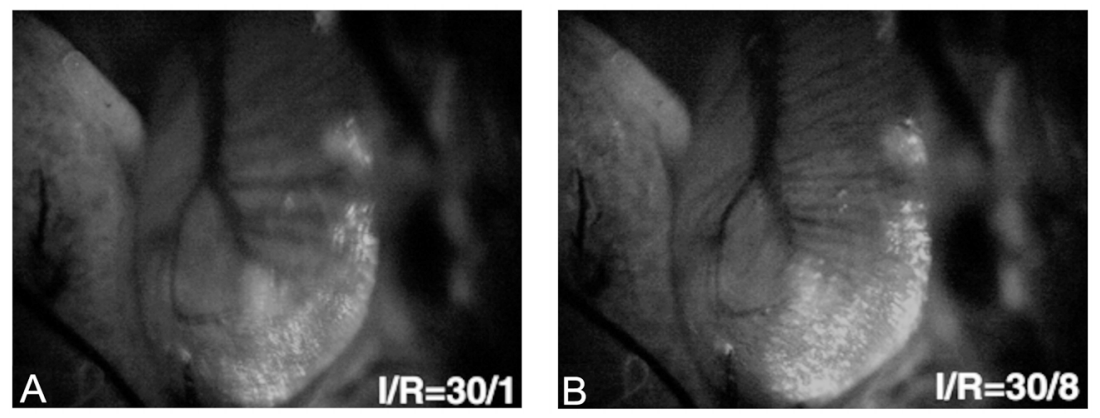

Figure 5:

In-vivo whole heart imaging of mice undergoing ischaemia (I) and reperfusion ( $R$ ). Images taken after 30 minutes of ischaemia and 1 and 8 minutes of reperfusion, respectively. Annexin A5 has been labeled with a green fluorescent molecule. Notice the increase in intensity of signal. Via this method, the externalization of PS can be monitored in a time dependent manner, allowing real time visualization of activation of the cell death program in the beating heart. For full color image see page 92. 
Detecting PS exposure in patients requires the development of an imaging tool suitable for non-invasive imaging. This has been achieved using nuclear medicine technology, as this profession has a long history of molecular imaging. The first method descibed to label annexin A5 radioactively was its iodination using ${ }^{125} I^{37,75}$ and later ${ }^{123} I^{76}$. However, due to better imaging properties and lower radiation exposure ${ }^{99 \mathrm{~m}} \mathrm{Technetium}\left({ }^{99 \mathrm{~m}} \mathrm{Tc}\right)$ was selected for labelling of Annexin A5. Labelling can be achieved trough a variety of methods ${ }^{4}$. Using ${ }^{99 \mathrm{~m}} \mathrm{Tc}$ Annexin A5, we have shown feasibility of detecting pathologic programmed cell death in patients with an cute myocardial infarction ${ }^{56}$ (Figure 6).

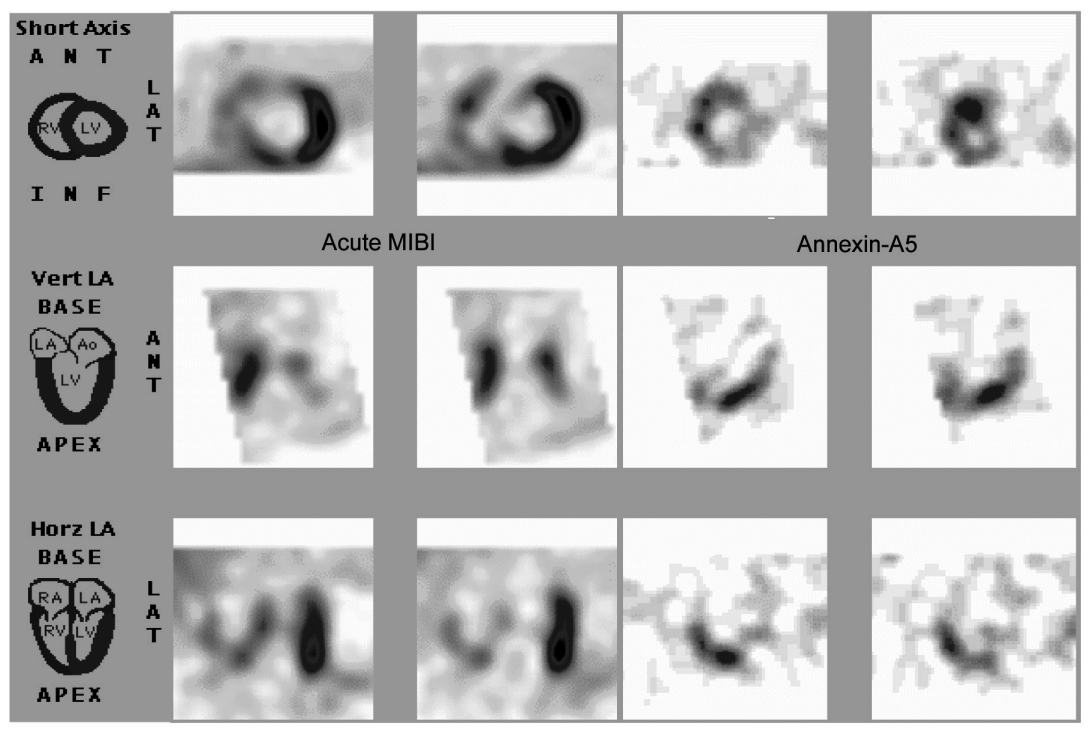

Figure 6:

Detection of cell death in a patient with acute myocardial infarction, using technetium labeled Annexin A5. The left panel shows perfusion imaging in the acute stage prior to opening of the occluded artery. The perfusion defect is used as a measure of the area at risk. The right panel shows imaging of the binding of technetium labeled Annexin A5 within the area at risk, indicating presence of programmed cell death in the area of infarction. For full color image see page 93.

\section{MOLECULAR IMAGING OF INFLAMMATION}

Inflammation is an important contributing factor in cardiovascular disease. As mentioned above, apoptosis is not the sole contributor to plaque instability. Instead, local inflammation and formation of a large necrotic lipid core may render atherosclerotic plaques vulnerable to rupture, Plaque rupture then causes the acute vascular syndrome. Autopsy studies have shown that vulnerable plaques involve $50-80 \%$ of the intravascular lumen. 
In addition, stenosis of more than $80 \%$ is usually not associated with plaque vulnerability, as these atherosclerotic lesions are mostly organized and stable. Therefore, luminography, such as achieved by coronary angiography, is a far from ideal to detect plaque instability. Instead, molecular imaging techniques have been used lately for detection of local inflammation. Such techniques include MRI, PET and SPECT imaging and usage of intravascular devices. MRI can employ targeted contast agents such as ultra small particles of iron oxide (USPIO's). USPIO's are retained in intraplaque macrophages, producing a hyperintense signal on MRI imaging ${ }^{77,78}$. Possibly, intravascular magnetic resonance imaging can be used in combination with these imaging agents for detailed local information of plaque biology. PET imaging of uptake of ${ }^{18} \mathrm{FDG}$ can increase glucose metabolism at the site of inflammation. This principle has been used successfully in vulnerable plaques in animals and humans. PET ${ }^{18} \mathrm{FDG}$ imaging is a quantifiable technique in imaging carotid artery atherosclerosis. However, high uptake of ${ }^{18} \mathrm{FDG}$ in myocardium makes coronary imaging difficult to achieve, although feasibility has been shown ${ }^{79}$. SPECT imaging of targeted agents involved in plaque instability such as labelled oxidated LDL and labelled matrix metalloproteinases (MMPs) have shown feasibility in animal studies. To date, clinical studies using these agents are lacking.

Finally, intravascular devices such as intravascular ultrasound (IVUS) and optical coherence tomography (OCT), possibly combined with targeted imaging agents, can detect local anatomy in great detail. IVUS has been used for plaque characterization in coronary atheroma in patients. Although highly promising, authors differ in definition of vulnerable IVUS characteristics. No prospective studies have been performed linking vulnerable characteristics to coronary events. Finally, the resolution of IVUS $(150$ to $300 \mu \mathrm{m}$ ) is too low to detect thin fibrous caps (50 to $75 \mu \mathrm{m}$ ). OCT does render enough resolution ( 4 to $20 \mu \mathrm{m}$ ). The technology is analogous to ultrasound, measuring the backreflection of infrared light rather than ultrasound. Animal studies have shown that OCT of atheroma correlates well with pathology specimens. Attenuation by blood and the limited tissue penetration may limit the yield of OCT, but can be partially overcome by balloon occlusion and saline flushing. Human studies are underway, and have thus far shown OCT to be feasible and safe. Indeed, preliminary studies have shown feasibility of detecting thin fibrous cap atheroma, a highly likely precursor for acute coronary syndromes. More work is underway identifying macrophage invasion and lipid content, but technical obstacles still have to be taken ${ }^{80}$. 


\section{BREAKING THE CODE: DETECTION OF BIOLOGY UNDERLYING CARDIOVASCULAR DISEASE}

As stated previously, molecular imaging of PS expression provides a feasible target for early detection of cardiovascular disease. In addition, proofof-concept has been obtained in patients with an acute myocardial infarction. This thesis aims to provide insights into biology underlying cardiovascular disease, focusing on the use of detection of PS exposure. In chapter two, we describe the use of radiolabeled Annexin A5 for detection of programmed cell death in patients with heart failure. Programmed cell death is an integral part of the pathophysiology of heart failure, and detecting it could predict clinical outcome and potentially identify patients at risk. We selected patients with an idiopathic dilated cardiomyopathy (IDCM), as previous studies have shown IDCM patients have a high rate of apoptosis. Potentially molecular imaging may select patients that would profit from cell death blocking agents. Chapter three illustrates the use of Annexin A5 imaging in a patient suffering from infectious endocarditis, and discusses the potential role of this imaging modality in the diagnostic workup of endocarditis. Chapter four shows the use of molecular imaging in detection of unstable plaque. Unstable atherosclerotic plaque is characterized by macrophage apoptosis, presence of fresh thrombus and macrophage activation. As chapters two, three and four shown, all these processes are characterized by PS expression, and therefore a target for Annexin imaging. Being the precursor to stroke and acute myocardial infarction, detection of unstable plaque may provide clinicians with a tool for preventative care, selecting high risk patients for invasive procedures. Chapter five demonstrates the use of Annexin A5 imaging in patients with an intracardiac mass. Making the diagnosis in these cases is challenging, as intracardiac masses are unsuitable for biopsy taking. Thus diagnosis is often made after surgery, thereby denying patients optimal treatment. We have aimed to come to a diagnosis prior to surgery. This could favorably influence clinical decision making. Chapter six will shortly summarize the results of our studies and compare them to other imaging techniques. In addition, future possibilities are discussed. 


\section{REFERENCES}

1. Kietselaer BL, Hofstra L, Dumont EA, Reutelingsperger $\mathrm{CP}$, Heidendal GA. The role of labeled Annexin A5 in imaging of programmed cell death. From animal to clinical imaging. Q J Nucl Med 2003; 47:349-61.

2. Kietselaer B, Reutelingsperger C, Hofstra L. Molecular Imaging of Programmed Cell Death; from basic mechanisms to clinical applications. In: Fussenegger M, ed. Cell Engineering: Apoptosis. Vol. 4. Dordrecht: Kluwer Publishers, 2004:307-328.

3. Hofstra L, Reutelingsperger C, Kietselaer B, Narula J, Strauss HW. Noninvasive detection of Cell Death in Myocardial Disorders. In: Beller GA, ed. Clinical Nuclear Cardiology. Philadelphia, Pe: Elsevier Mosby, 2005:649-658.

4. Boersma HH, Kietselaer BL, Stolk LM, et al. Past, present, and future of annexin A5: from protein discovery to clinical applications. J Nucl Med 2005; 46:2035-50.

5. RIVM. Volksgezondheid Toekomst Verkenning, Nationaal Kompas Volksgezondheid. http://www.rivm.nl 2006.

6. Heart Disease and Stroke Statistics - 2004 Update. Dallas, Texas: American Heart Association, 2004.

7. Kietselaer BLJH, Thimister PW, Reutelingsperger CPM, et al. Molecular imaging of cell death in intracardiac tumours. Netherlands Heart Journal 2002; 10:313-7.

8. Weissleder R, Mahmood U. Molecular imaging. Radiology 2001; 219:31633.

9. Massoud TF, Gambhir SS. Molecular imaging in living subjects: seeing fundamental biological processes in a new light. Genes Dev 2003; 17:545-80.

10. Bretscher MS. Asymmetrical lipid bilayer structure for biological membranes. Nat New Biol 1972; 236:11-2.

11. Bell RM, Ballas LM, Coleman RA. Lipid topogenesis. J Lipid Res 1981; 22:391-403.

12. Buton $X$, Morrot G, Fellmann P, Seigneuret M. Ultrafast glycerophospholipid-selective transbilayer motion mediated by a protein in the endoplasmic reticulum membrane. J Biol Chem 1996; 271:6651-7.

13. Kawashima Y, Bell RM. Assembly of the endoplasmic reticulum phospholipid bilayer. Transporters for phosphatidylcholine and metabolites. J Biol Chem 1987; 262:16495-502.

14. Kornberg RD, McConnell HM. Inside-outside transitions of phospholipids in vesicle membranes. Biochemistry 1971; 10:1111-20.

15. Seigneuret M, Devaux PF. ATP-dependent asymmetric distribution of spin-labeled phospholipids in the erythrocyte membrane: relation to shape changes. Proc Natl Acad Sci U S A 1984; 81:3751-5. 
16. Connor J, Gillum K, Schroit AJ. Maintenance of lipid asymmetry in red blood cells and ghosts: effect of divalent cations and serum albumin on the transbilayer distribution of phosphatidylserine. Biochim Biophys Acta 1990; 1025:82-6.

17. Sune A, Bette-Bobillo P, Bienvenue A, Fellmann P, Devaux PF. Selective outside-inside translocation of aminophospholipids in human platelets. Biochemistry 1987; 26:2972-8.

18. Zachowski A, Herrmann A, Paraf A, Devaux PF. Phospholipid outsideinside translocation in lymphocyte plasma membranes is a proteinmediated phenomenon. Biochim Biophys Acta 1987; 897:197-200.

19. Julien M, Tournier JF, Tocanne JF. Differences in the transbilayer and lateral motions of fluorescent analogs of phosphatidylcholine and phosphatidylethanolamine in the apical plasma membrane of bovine aortic endothelial cells. Exp Cell Res 1993; 208:387-97.

20. Martin OC, Pagano RE. Transbilayer movement of fluorescent analogs of phosphatidylserine and phosphatidylethanolamine at the plasma membrane of cultured cells. Evidence for a protein-mediated and ATPdependent process(es). J Biol Chem 1987; 262:5890-8.

21. Muller P, Pomorski T, Porwoli S, Tauber R, Herrmann A. Transverse movement of spin-labeled phospholipids in the plasma membrane of a hepatocytic cell line (HepG2): implications for biliary lipid secretion. Hepatology 1996; 24:1497-503.

22. Pomorski T, Herrmann A, Muller P, van Meer G, Burger K. Proteinmediated inward translocation of phospholipids occurs in both the apical and basolateral plasma membrane domains of epithelial cells. Biochemistry 1999; 38:142-50.

23. Daleke DL, Lyles JV. Identification and purification of aminophospholipid flippases. Biochim Biophys Acta 2000; 1486:108-27.

24. Brooks-Wilson A, Marcil M, Clee SM, et al. Mutations in ABC1 in Tangier disease and familial high-density lipoprotein deficiency. Nat Genet 1999; 22:336-45.

25. van Helvoort A, Smith AJ, Sprong $H$, et al. MDR1 P-glycoprotein is a lipid translocase of broad specificity, while MDR3 P-glycoprotein specifically translocates phosphatidylcholine. Cell 1996; 87:507-17.

26. Luciani MF, Chimini G. The ATP binding cassette transporter ABC1, is required for the engulfment of corpses generated by apoptotic cell death. Embo J 1996; 15:226-35.

27. Fadok VA, Voelker DR, Campbell PA, Cohen JJ, Bratton DL, Henson PM. Exposure of phosphatidylserine on the surface of apoptotic lymphocytes triggers specific recognition and removal by macrophages. J Immunol 1992; 148:2207-16. 
28. van den Eijnde SM, Boshart L, Baehrecke EH, De Zeeuw Cl, Reutelingsperger $\mathrm{CP}$, Vermeij-Keers $\mathrm{C}$. Cell surface exposure of phosphatidylserine during apoptosis is phylogenetically conserved. Apoptosis 1998; 3:916.

29. Schlegel RA, Williamson P. Phosphatidylserine, a death knell. Cell Death Differ 2001; 8:551-63.

30. Frasch SC, Henson PM, Kailey JM, et al. Regulation of phospholipid scramblase activity during apoptosis and cell activation by protein kinase Cdelta. J Biol Chem 2000; 275:23065-73.

31. Ferraro-Peyret C, Quemeneur L, Flacher M, Revillard JP, Genestier L. Caspase-independent phosphatidylserine exposure during apoptosis of primary T lymphocytes. J Immunol 2002; 169:4805-10.

32. Zou H, Henzel WJ, Liu X, Lutschg A, Wang X. Apaf-1, a human protein homologous to $\mathrm{C}$. elegans CED-4, participates in cytochrome cdependent activation of caspase-3. Cell 1997; 90:405-13.

33. Williamson P, Bevers EM, Smeets EF, Comfurius P, Schlegel RA, Zwaal RF. Continuous analysis of the mechanism of activated transbilayer lipid movement in platelets. Biochemistry 1995; 34:10448-55.

34. Dillon SR, Mancini M, Rosen A, Schlissel MS. Annexin V binds to viable $B$ cells and colocalizes with a marker of lipid rafts upon B cell receptor activation. J Immunol 2000; 164:1322-32.

35. Comfurius P, Senden JM, Tilly RH, Schroit AJ, Bevers EM, Zwaal RF. Loss of membrane phospholipid asymmetry in platelets and red cells may be associated with calcium-induced shedding of plasma membrane and inhibition of aminophospholipid translocase. Biochim Biophys Acta 1990; 1026:153-60.

36. Zhai X, Srivastava A, Drummond DC, Daleke D, Lentz BR. Phosphatidylserine binding alters the conformation and specifically enhances the cofactor activity of bovine factor $\mathrm{Va}$. Biochemistry 2002; 41:5675-84.

37. Stratton JR, Dewhurst TA, Kasina $S$, et al. Selective uptake of radiolabeled annexin $V$ on acute porcine left atrial thrombi. Circulation 1995; 92:3113-21.

38. van den Eijnde SM, Luijsterburg AJ, Boshart L, et al. In situ detection of apoptosis during embryogenesis with annexin $\mathrm{V}$ : from whole mount to ultrastructure. Cytometry 1997; 29:313-20.

39. Callahan MK, Williamson P, Schlegel RA. Surface expression of phosphatidylserine on macrophages is required for phagocytosis of apoptotic thymocytes. Cell Death Differ 2000; 7:645-53.

40. Fadok VA, Bratton DL, Rose DM, Pearson A, Ezekewitz RA, Henson PM. A receptor for phosphatidylserine-specific clearance of apoptotic cells. Nature 2000; 405:85-90.

41. Savill J, Fadok V. Corpse clearance defines the meaning of cell death. Nature 2000; 407:784-8. 
42. Ogden CA, deCathelineau A, Hoffmann PR, et al. C1q and mannose binding lectin engagement of cell surface calreticulin and CD91 initiates macropinocytosis and uptake of apoptotic cells. J Exp Med 2001; 194:781-95.

43. Fadok VA, Bratton DL, Henson PM. Phagocyte receptors for apoptotic cells: recognition, uptake, and consequences. J Clin Invest 2001; 108:957-62.

44. Hanayama R, Tanaka M, Miwa K, Shinohara A, Iwamatsu A, Nagata S. Identification of a factor that links apoptotic cells to phagocytes. Nature 2002; 417:182-7.

45. Hanayama R, Tanaka M, Miyasaka K, et al. Autoimmune disease and impaired uptake of apoptotic cells in MFG-E8-deficient mice. Science 2004; 304:1147-50.

46. Zullig S, Hengartner MO. Cell biology. Tickling macrophages, a serious business. Science 2004; 304:1123-4.

47. Wackers FJ, Vogt-Hoerner G. [Presence of a local bionecrosis in the intra-epithelial stratum of the acini of the human mammary gland]. Ann Anat Pathol (Paris) 1967; 12:21-34.

48. Kerr JF, Wyllie AH, Currie AR. Apoptosis: a basic biological phenomenon with wide-ranging implications in tissue kinetics. Br J Cancer 1972; 26:239-57.

49. Wyllie AH. Glucocorticoid-induced thymocyte apoptosis is associated with endogenous endonuclease activation. Nature 1980; 284:555-6.

50. Wyllie AH, Kerr JF, Currie AR. Cell death: the significance of apoptosis. Int Rev Cytol 1980; 68:251-306.

51. Hengartner MO. The biochemistry of apoptosis. Nature 2000; 407:770-6.

52. Leist $M$, Jaattela $M$. Four deaths and a funeral: from caspases to alternative mechanisms. Nat Rev Mol Cell Biol 2001; 2:589-98.

53. Olivetti G, Abbi R, Quaini F, et al. Apoptosis in the failing human heart. N Engl J Med 1997; 336:1131-41.

54. Narula J, Haider N, Virmani R, et al. Apoptosis in myocytes in end-stage heart failure. $N$ Engl J Med 1996; 335:1182-9.

55. Mallat Z, Tedgui A, Fontaliran F, Frank R, Durigon M, Fontaine G. Evidence of apoptosis in arrhythmogenic right ventricular dysplasia. $\mathrm{N}$ Engl J Med 1996; 335:1190-6.

56. Hofstra L, Liem IH, Dumont EA, et al. Visualisation of cell death in vivo in patients with acute myocardial infarction. Lancet 2000; 356:209-12.

57. Dumont EA, Hofstra L, van Heerde WL, et al. Cardiomyocyte death induced by myocardial ischemia and reperfusion: measurement with recombinant human annexin- $\mathrm{V}$ in a mouse model. Circulation 2000; 102:1564-8.

58. Adams JW, Sakata Y, Davis MG, et al. Enhanced Galphaq signaling: a common pathway mediates cardiac hypertrophy and apoptotic heart failure. Proc Natl Acad Sci U S A 1998; 95:10140-5. 
59. Hirota H, Chen J, Betz UA, et al. Loss of a gp130 cardiac muscle cell survival pathway is a critical event in the onset of heart failure during biomechanical stress. Cell 1999; 97:189-98.

60. Scarabelli TM, Stephanou A, Pasini E, et al. Different signaling pathways induce apoptosis in endothelial cells and cardiac myocytes during ischemia/reperfusion injury. Circ Res 2002; 90:745-8.

61. Becker LB, vanden Hoek TL, Shao ZH, Li CQ, Schumacker PT. Generation of superoxide in cardiomyocytes during ischemia before reperfusion. Am J Physiol 1999; 277:H2240-6.

62. Holly TA, Drincic A, Byun $\mathrm{Y}$, et al. Caspase inhibition reduces myocyte cell death induced by myocardial ischemia and reperfusion in vivo. J Mol Cell Cardiol 1999; 31:1709-15.

63. Communal C, Singh K, Pimentel DR, Colucci WS. Norepinephrine stimulates apoptosis in adult rat ventricular myocytes by activation of the beta-adrenergic pathway. Circulation 1998; 98:1329-34.

64. Bialik S, Geenen DL, Sasson IE, et al. Myocyte apoptosis during acute myocardial infarction in the mouse localizes to hypoxic regions but occurs independently of p53. J Clin Invest 1997; 100:1363-72.

65. Kajstura J, Cheng W, Reiss K, et al. Apoptotic and necrotic myocyte cell deaths are independent contributing variables of infarct size in rats. Lab Invest 1996; 74:86-107.

66. Hayakawa Y, Chandra M, Miao W, et al. Inhibition of cardiac myocyte apoptosis improves cardiac function and abolishes mortality in the peripartum cardiomyopathy of Galpha(q) transgenic mice. Circulation 2003; 108:3036-41.

67. Gavrieli Y, Sherman Y, Ben-Sasson SA. Identification of programmed cell death in situ via specific labeling of nuclear DNA fragmentation. J Cell Biol 1992; 119:493-501.

68. Kanoh M, Takemura G, Misao J, et al. Significance of myocytes with positive DNA in situ nick end-labeling (TUNEL) in hearts with dilated cardiomyopathy: not apoptosis but DNA repair. Circulation 1999; 99:2757-64.

69. Sakahira $H$, Enari $M$, Nagata $S$. Cleavage of CAD inhibitor in CAD activation and DNA degradation during apoptosis. Nature 1998; 391:969.

70. Kohler C, Orrenius S, Zhivotovsky B. Evaluation of caspase activity in apoptotic cells. J Immunol Methods 2002; 265:97-110.

71. Zhao M, Beauregard DA, Loizou L, Davletov B, Brindle KM. Noninvasive detection of apoptosis using magnetic resonance imaging and a targeted contrast agent. Nat Med 2001; 7:1241-1244.

72. Koopman G, Reutelingsperger CP, Kuijten GA, Keehnen RM, Pals ST, van Oers $\mathrm{MH}$. Annexin $\mathrm{V}$ for flow cytometric detection of phosphatidylserine expression on B cells undergoing apoptosis. Blood 1994; 84:1415-20. 
73. Martin SJ, Reutelingsperger CP, McGahon AJ, et al. Early redistribution of plasma membrane phosphatidylserine is a general feature of apoptosis regardless of the initiating stimulus: inhibition by overexpression of Bcl-2 and Abl. J Exp Med 1995; 182:1545-56.

74. van Engeland M, Ramaekers FC, Schutte B, Reutelingsperger CP. A novel assay to measure loss of plasma membrane asymmetry during apoptosis of adherent cells in culture. Cytometry 1996; 24:131-9.

75. Tait JF, Cerqueira MD, Dewhurst TA, Fujikawa K, Ritchie JL, Stratton JR. Evaluation of annexin $\mathrm{V}$ as a platelet-directed thrombus targeting agent. Thromb Res 1994; 75:491-501.

76. Lahorte C, Slegers G, Philippe J, Van de Wiele C, Dierckx RA. Synthesis and in vitro evaluation of 123I-labelled human recombinant annexin $\mathrm{V}$. Biomol Eng 2001; 17:51-3.

77. Kooi ME, Cappendijk VC, Cleutjens KB, et al. Accumulation of ultrasmall superparamagnetic particles of iron oxide in human atherosclerotic plaques can be detected by in vivo magnetic resonance imaging. Circulation 2003; 107:2453-8.

78. Weissleder R, Elizondo G, Wittenberg J, Rabito CA, Bengele HH, Josephson L. Ultrasmall superparamagnetic iron oxide: characterization of a new class of contrast agents for MR imaging. Radiology 1990; 175:489-93.

79. Davies JR, Rudd JF, Fryer TD, Weissberg PL. Targeting the vulnerable plaque: the evolving role of nuclear imaging. J Nucl Cardiol 2005; 12:234-46.

80. Stamper D, Weissman NJ, Brezinski M. Plaque characterization with optical coherence tomography. J Am Coll Cardiol 2006; 47:C69-79. 


\section{CHAPTER 2}

Non-invasive Detection of Programmed Cell Loss with ${ }^{99 \mathrm{~m}} \mathrm{Tc}$ labeled Annexin A5 in Heart Failure

Bas L.J.H. Kietselaer, Chris P.M. Reutelingsperger, Hendrikus H. Boersma, Guido A.K. Heidendal, Ing Han Liem, Harry J.G.M. Crijns, Jagat Narula and Leo Hofstra 


\section{ABSTRACT}

Apoptosis or programmed cell death (PCD) contributes to the decline in ventricular function in heart failure. Since apoptosis comprises a programmed cascade of events, it is potentially reversible, and timely intervention should delay the development of cardiomyopathy. ${ }^{99 \mathrm{~m}} \mathrm{Tc}$-labeled Annexin A5 has been successfully employed for the non-invasive detection of PCD in myocardial infarction and heart transplant rejection. The present study evaluates the role of Annexin A5 imaging for detection of PCD in heart failure patients.

Methods: Annexin A5 imaging was performed in 9 consecutive heart failure patients with advanced non-ischemic cardiomyopathy (dilated, $\mathrm{N}=8$; and hypertrophic, $\mathrm{N}=1$ ), and also in two relatives of the hypertrophic cardiomyopathy patient having the same genetic background but no heart failure. Results: Four patients with dilated cardiomyopathy and one with hypertrophic cardiomyopathy and heart failure showed focal, multifocal or global left ventricular uptake of Annexin A5. No uptake was visualized in the remaining 4 patients, and 2 controls. All cases showing Annexin A5 uptake within the left ventricle suffered significant reduction in left ventricular function and/or functional class. In cases with no Annexin A5 uptake, left ventricular function and clinical status remained stable.

Conclusions: These data indicate the feasibility of non-invasive PCD detection with annexin imaging in heart failure patients. Annexin A5 uptake is associated with deterioration in left ventricular function and may lend itself to development of novel management strategies. 


\section{INTRODUCTION}

Heart failure is evolving to be the most important cardiovascular health problem ${ }^{81}$ and strategies that allow recognition of potentially reversible myocardial damage may have significant clinical impact. Heart failure is

characterized by inexorable deterioration in ventricular function ${ }^{82,}{ }^{83}$. Apoptosis or programmed cell death (PCD) of cardiomyocytes has been proposed as an important process that mediates the slow ongoing loss of heart muscle cells and ventricular dysfunction ${ }^{4-7}$. Anti-apoptotic intervention is known to delay and prevent the occurrence or minimize the severity of heart failure in animal models ${ }^{8,9}$. Since apoptosis is genetically programmed and can be modified, it is important to develop techniques for noninvasive detection of PCD in heart failure ${ }^{10}$.

Activation of caspase 3, the hallmark of PCD, leads to alteration in phospholipid assortment in sarcolemmal lipid bilayer resulting in externalization of phosphatidyl serine(PS) to the outer surface of the cell membrane ${ }^{11}$,

12. PS externalization has been successfully detected non-invasively by radionuclide imaging with ${ }^{99 \mathrm{~m}} \mathrm{Tc}$-labeled Annexin $\mathrm{A} 5^{13,14}$. The clinical feasibility of imaging with Annexin A5 has been demonstrated in patients presenting with acute myocardial infarction ${ }^{13}$, cardiac allograft rejection ${ }^{15}$, and malignant intra-myocardial masses ${ }^{14}$. We studied the feasibility of Annexin A5 imaging for the detection of PCD in a small group of patients with advanced heart failure.

\section{METHODS}

\section{Patients}

Annexin A5 imaging was performed in nine consecutive patients admitted with non-ischemic cardiomyopathy and advanced heart failure. Ages ranged from 35-64 years, six of the nine patients were males. New York Heart Association (NYHA) class II, III, and IV symptoms were reported by 1 , 5 and 3 patients, respectively. Eight patients had idiopathic dilated cardiomyopathy (\#1-8); four of them $(\# 3,6,7,8)$ had shown recent worsening of failure with a reduction of at least one NYHA functional class during the past 3 months. The remaining patient (\#9) developed heart failure secondary to familial hypertrophic cardiomyopathy caused by a mutation in the myosin gene at locus $14 q 11-q 12$. Two relatives of patient \#9 with the same myosin gene mutation (ages 33 and 36 years, both females), a hypertrophic echocardiographic phenotype and normal LVEF also underwent Annexin A5 imaging as hypertrophic but non-failing controls. Patient characteristics are summarized in table 1. 
Table 1. Patient chararteristics and outcome of Annexin A5 SPECT.

\begin{tabular}{l|lllllll} 
Pt & Sex/age & Dx & $\begin{array}{l}\text { NYHA } \\
\text { prior }\end{array}$ & $\begin{array}{l}\text { NYHA } \\
\text { study }\end{array}$ & $\begin{array}{l}\text { LVEF } \\
\text { study }\end{array}$ & $\begin{array}{l}\text { LVEF } \\
\text { post }\end{array}$ & SPECT \\
\hline 1 & M/63 & DCM & III & III & $25 \%$ & $30 \%$ & Negative \\
\hline 2 & M/35 & DCM & II & II & $26 \%$ & $50 \%$ & Negative \\
\hline 3 & F/39 & DCM I & III & $45 \%$ & $46 \%$ & Focal \\
\hline 4 & M/52 & DCM & III & III & $31 \%$ & $34 \%$ & Negative \\
\hline 5 & M/50 & DCM & III & III & $17 \%$ & $22 \%$ & Negative \\
\hline 6 & M/58 & DCM & II & IV & $48 \%$ & $24 \%$ & Focal, mainly lateral \\
\hline 7 & F/64 & DCM & II & III & $21 \%$ & $15 \%$ & Multifocal \\
\hline 8 & F/41 & DCM & III & IV & $20 \%$ & $22 \%$ & Negative \\
\hline 9 & F/33 & HCM & II & IV & $26 \%$ & $15 \%$ & Positive, Diffuse LV \\
\hline 10 & F/36 & HCM I & I & $52 \%$ & N/A & Negative \\
\hline 11 & F/37 & HCM I & I & $73 \%$ & N/A & Negative
\end{tabular}

$\mathrm{Pt}=$ patient number; $\mathrm{Dx}=$ diagnosis; $\mathrm{DCM}=$ dilated cardiomyopathy $\mathrm{HCM}=$ hypertrophic cardiomyopathy; NYHA prior = New York Heart Association functional class prior to study; NYHA study = NYHA class at time of study; LVEF study = LVEF at time of Annexin imaging; LVEF post = LVEF after one year follow up. SPECT = Outcome of the Annexin A5 imaging study.

Echocardiography was performed in all patients at the time of imaging. Left ventricular ejection fraction (LVEF) was assessed by 2D echocardiography. Tracing of the inner myocardial wall of the left ventricle in both end-diastolic and end-systolic phase was performed. Using modified Simpson's analysis 16, we assessed LVEF. Patients were followed-up routinely in the cardiology department of our hospital as outpatients. LVEF was reassessed by echocardiography after one year in all patients except the hypertrophic controls.

\section{Annexin A5 Labeling and SPECT Study Protocol:}

Human recombinant Annexin A5 (Theseus Imaging Corporation, Boston, MA) was labeled with $1 \mathrm{GBq}$ of ${ }^{99 \mathrm{~m}} \mathrm{Tc}$ for imaging. Six hours prior to imaging, ${ }^{99 \mathrm{~m}} \mathrm{Tc}$-Annexin $\mathrm{A} 5$ was administered intravenously. In addition, 32 to 48 $\mathrm{MBq}$ of ${ }^{201} \mathrm{Tl}$ was administered 30 minutes before imaging. All scintigraphic studies were performed using a MultiSPECT2 dual-head gamma camera (Siemens, Hoffman Estate, IL). A dual isotope imaging protocol was used to acquire ${ }^{99 \mathrm{~m}} \mathrm{Tc}$ and ${ }^{201} \mathrm{Tl}$ data simultaneously. For ${ }^{99 \mathrm{~m}} \mathrm{Tc}$ data, an energy peak of $140 \mathrm{keV}$ with a window of $10 \%$ was used. ${ }^{201} \mathrm{TI}$ data were acquired using a peak of $166 \mathrm{keV}$ and $70 \mathrm{keV}$ and windows of $15 \%$ and $20 \%$, respectively. We used a $64 \times 64$ matrix and 64 angled views, counting each angle for 60 seconds. Studies were reconstructed with a back-projection method. Standard views of the left ventricle were constructed using the ${ }^{201} \mathrm{Tl}$ dataset. Limits and orientation of the left ventricle were transferred onto the ${ }^{99 \mathrm{~m}} \mathrm{Tc}$ Annexin dataset. Because of simultaneous acquisition of these data, we 
were able to precisely localize myocardial uptake of ${ }^{99 \mathrm{~m}}$ Tc-Annexin A5. Radiation exposure was calculated to between 3.4 to $4.5 \mathrm{mSv}$. Two readers $(\mathrm{GH}, \mathrm{IL})$, blinded to clinical information, assessed SPECT data independently. This study complies with the declaration of Helsinki, and was approved by the institutional review committee of the University Hospital of Maastricht. All subjects gave written informed consent.

\section{RESULTS}

Patients \#1-9 had advanced heart failure due to nonischemic cardiomyopathy. Prior to entering the study, the absence of coronary artery disease was confirmed by coronary angiography. Echocardiography did not show regional wall motion abnormalities as determined by standard 2D echo. LVEF ranged from 15 to $31 \%$ at time of Annexin A5 imaging. LVEF in two controls subjects was $52 \%$ and $73 \%$, respectively.

Of the nine CHF patients, five showed Annexin A5 uptake in the left ventricular myocardium; no uptake was observed in the right ventricle. The uptake was focal in one patient (\#6), multifocal in two (\#3, 7) (Figure 1A), and diffuse in one patient (\#9) (Figure 1B). Myocardial perfusion was essentially normal in these patients and the areas of Annexin A5 uptake did not correspond to a single coronary territory as often observed in myocardial infarction. All 4 dilated cardiomyopathy patients with positive Annexin A5 uptake had sustained significant recent worsening or recent onset of heart failure in the last 3 months. Similarly, the patient with the myosin gene mutation demonstrated a positive, diffuse uptake and had experienced a substantial decrease in LVEF in the past 6 months. 

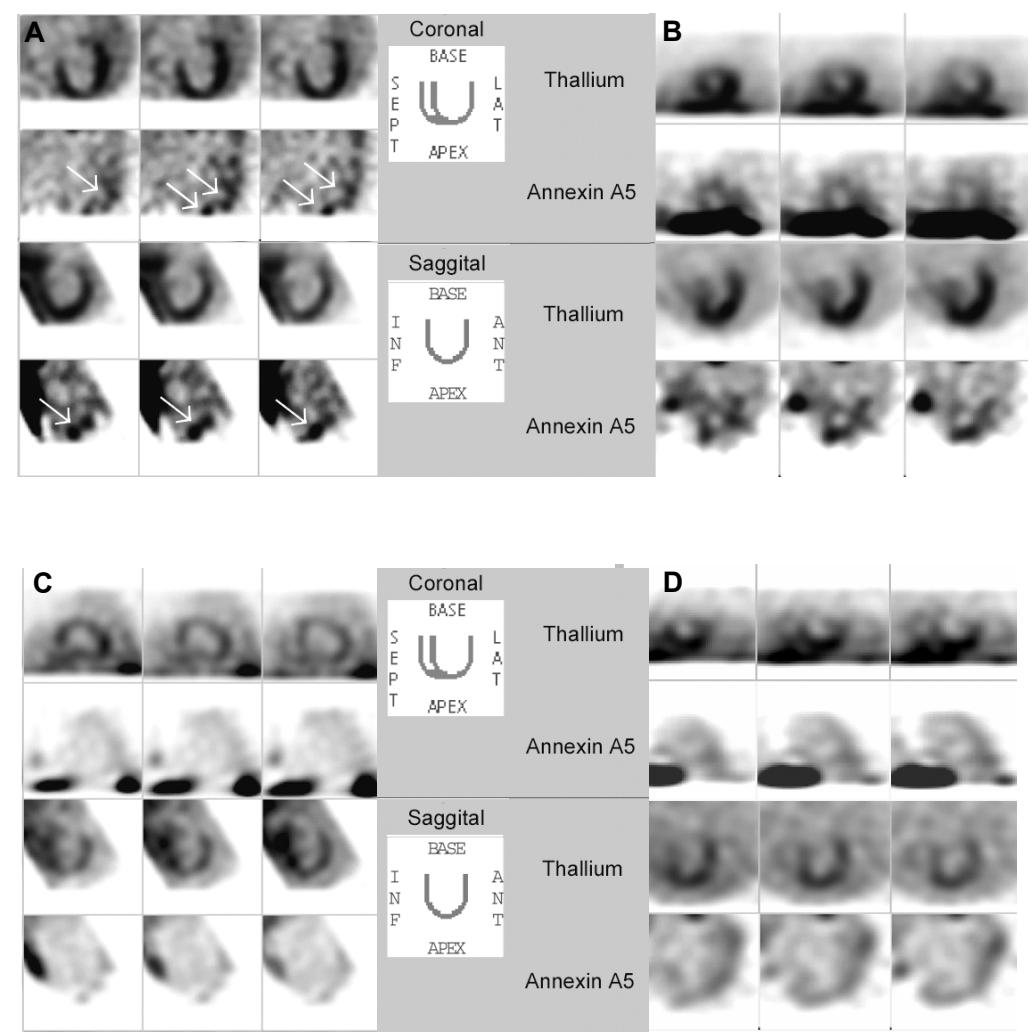

\section{Figure 1:}

Dual isotope imaging using ${ }^{201} \mathrm{Tl}$ imaging for $L$ Contour detection and simultaneous imaging of radiolabeled Annexin $A 5$ in patients with dilated cardiomyopathy (DCM). SAX: Short axis LAX: Long axis 201Thal: 201 TI Anx: ${ }^{99 m}$ TC labeled Annexin A5. A: DCM patient with rapid deterioration of $L V$ function. Note the focal uptake in the apex and lateral wall, and slight septal uptake. B: DCM patient in acute heart failure. Note the global uptake of radiolabeled Annexin A5. C: DCM patient in stable clinical condition. Note the absence of uptake, even when the image is enhanced to the extent that background radioactivity can be observed. D: control case.

The remaining four heart failure patients did not show uptake of the radiotracer (Figure 1C). These patients had poor LV function (LVEF $=25$ to 31\%) but had no recent evidence of worsening of heart failure. The 2 family members of HCM patient, with the myosin gene mutation and echocardiographic evidence of LV hypertrophy and preserved LVEF did not show radiolabeled annexin uptake (Figure 1D).

During follow up of one year the four patients with positive Annexin A5 uptake, on average, showed a decline in LVEF. On the other hand in the Annexin A5 negative cases LVEF remained stable or increased somewhat after one year of follow up. Figure 2 depicts the change in ejection fraction, 
subtracting LVEF at time of imaging from LVEF one year after imaging. Student $T$ testing for paired samples shows a significant difference between patients with positive and negative Annexin A5 scan ( $p=0.038$ ).

Left ventricular ejection fraction one year post imaging

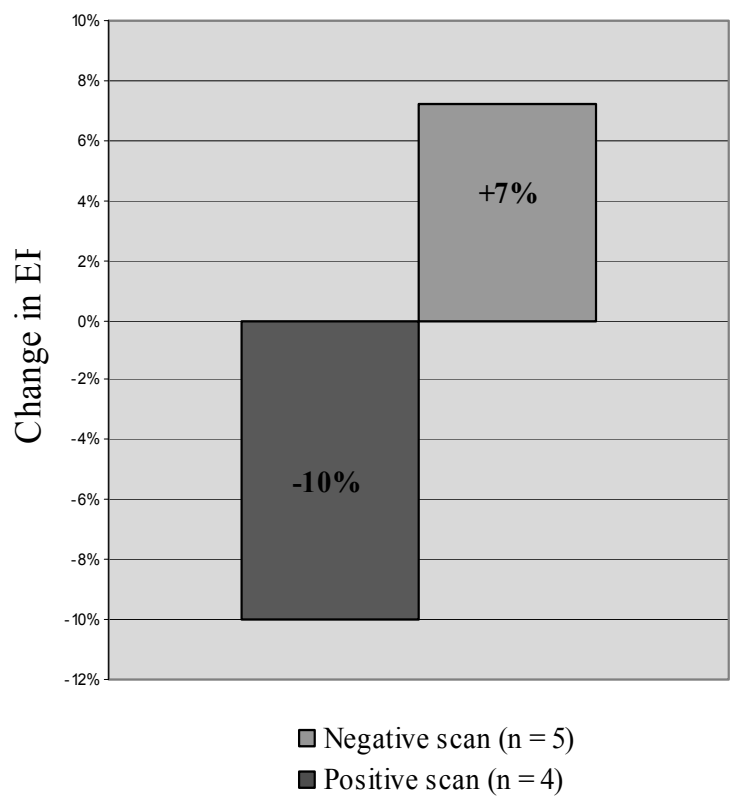

Figure 2:

Change in left ventricular ejection fraction one year after Annexin imaging. Green bar shows patients with a negative scan (mean EF increase $7 \%$ ), red bar shows patients with a positive scan (mean EF decrease 10\%). $P=0.038$.

\section{DISCUSSION}

Apoptosis in Heart Failure:

PCD contributes to slow ongoing myocardial dysfunction in heart failure ${ }^{17}$. It has been demonstrated that cytokinemia and ischemic/oxidative stress lead to release of cytochrome $\mathrm{c}$ from the mitochondria into the cytoplasmic compartment and lead to activation of caspase $3^{18}$. Active caspase 3 cleaves contractile proteins and activates DNA fragmentation enzymes. The loss of cytochrome c (hence the loss of energy production mechanism in mitochondria) and the fragmentation of contractile proteins contribute to 
decline in left ventricular function. Activation of caspase 3 also results in scrambling of cell membrane phospholipds, expression of PS (target for annexin imaging). However, there is simultaneous activation of various anti-apoptotic factors in the failing myocardium that inhibit caspase mediated activation of DNA-ses. Such protective steps represent the survival instinct of the apoptotic myocardium and result in interruption of the apoptotic process ${ }^{19-21}$. The more the anti-apoptotic factors, the better should be the survival of cardiomyocytes. On the other hand, more activation of caspase 3 results in more PS exposure, and presumably in a worse prognosis.

\section{Noninvasive imaging PCD}

Radionuclide imaging targets cell surface alterations to non-invasively recognize various forms of cell death associated with cardiovascular diseases ${ }^{13,15,22}$. Myocardial necrosis is characterized by a loss of sarcolemmal integrity, with the cell membrane allowing free access to radiotracers such as glucarate (binding to positively-charged histones in the disintegrating nuclei) and antimyosin antibody (binding to fragmenting insoluble heavy chain myosin molecules) ${ }^{23}$. On the other hand, the sarcolemma remains intact in PCD, but the asymmetry of the phospholipid distribution in lipid bilayer of the membrane is lost ${ }^{24}$. As such, abundant PS is exteriorized to the outer surface of membrane that serves as a marker for macrophage phagocytosis ${ }^{24}$. An endogenous protein, Annexin A5, has high affinity for PS, and has therefore been successfully used for the detection of PCD in vivo $^{13,22}$. PS exposure is closely linked to the activation of the executioner caspase 3 and can be prevented by administration of caspase inhibitors ${ }^{25}$. These cell death inhibitors have been shown to reduce the extent of myocardial damage in various myocardial pathologies ${ }^{8,25}$. The present study confirms the feasibility of Annexin A5 imaging for the detection of PCD in heart failure patients. Annexin A5 uptake was seen predominantly in those patients who had demonstrated a recent worsening in their LV function and/or functional class. In addition, these patients on average continued to show a decrease in LVEF up to one year in follow up (Figure 2).

\section{Other Noninvasive Imaging Studies in Heart Failure}

Previous imaging studies for detection of cell death in heart failure have been performed using antimyosin antibodies, showing evidence of myocardial necrosis in such patients ${ }^{23,26}$. Patients with positive antimyosin uptake were shown to have a high likelihood of myocarditis or evidence of non inflammatory myocyte degeneration in their endomyocardial biopsy samples. Patients with positive antimyosin scans showed functional improvement over time in contrast to those with negative antimyosin scans. The functional improvement in antimyosin-positive patients appears to be counter-intuitive. It was proposed that the antimyosin-positivity in dilated 
cardiomyopathy merely represented the extent of acute myocardial insult and the accompanying irreversibly damaged, antimyosin-negative myocytes were responsible for functional resolution ${ }^{23}$. This is in contrast to Annexin A5 imaging, where annexin-positive patients continue to sustain a decrease in LV function, and those with negative scans improve their LV function. We can only surmise that the antimyosin positive cells were an indirect marker of reversible cells, whereas the annexin-positive cells represent the true state of balance of pro-apoptotic and anti-apoptotic factors in the cardiomyocytes, and should be more predictive of prognosis. It is apparent that the cells with lower amount of anti-apoptotic factors (hence more PS expression and Annexin A5 positivity) would be better candidates for exogenous anti-apoptotic therapy. These findings have been translated into figure 3.

\section{Limitations of the Study}

These data should be interpreted carefully because of inclusion of a small number of patients. Further prospective trials including larger number of dilated cardiomyopathy patients with sequential scans and functional follow ups may clarify the current observations. As ${ }^{201} \mathrm{TI}$ gamma photons also have energy peak at $166 \mathrm{keV}$, there may be some downscatter into the $140 \mathrm{keV}$ window of ${ }^{99 \mathrm{M}} \mathrm{Tc}$. However, this downscatter was not observed in the family members of the HCM patient (Figure 1D). In addition, we did not observe downscatter in patients included in other studies (unpublished data). Furthermore, Annexin A5 uptake is focal in most patients, whereas downscatter from ${ }^{201} \mathrm{TI}$ should appear throughout the left ventricle. Endomyocardial biopsies were not performed in the present study. As biopsies are not likely to influence management strategy, the ethical committee did not allow the biopsies for the research purposes and for mere comparison with the results of Annexin A5 scans. In addition, serial Annexin A5 scans were also not allowed. The lack of endomyocardial biopsies precludes the diagnosis of myocarditis in scan-positive patients. Since none of the scanpositive patients showed improvement of LVEF, the likelihood of myocarditis in those cases is low. 


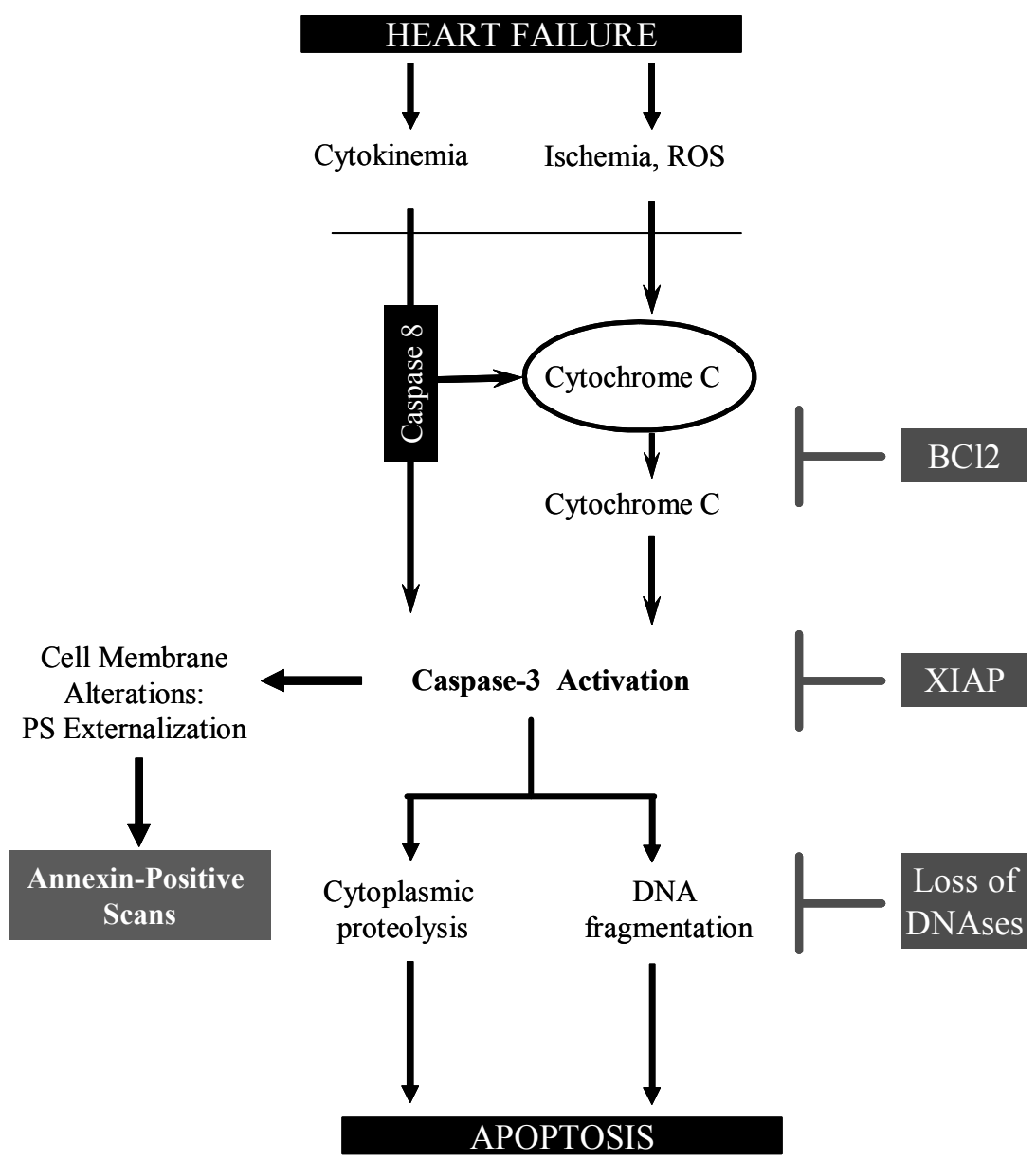

\section{Figure 3:}

Cytokine and oxidative stress (ROS) in heart failure lead to caspase 3 activation by release of cytochrome c from mitochondria into cytoplasmic compartment. Activation of caspase 3 results in cytoplasmic proteolysis and DNA fragmentation, and hence apoptosis. Endogenous upregulation of $\mathrm{BCl} 2$ and XIAP like proteins and loss of DNA fragmentation factors prevent completion of apoptotic process (apoptosis interruptus). The amount of activated caspase 3 is determined by the balance of antiapoptotic and pro-apoptotic factors. Less the endogenous anti-apoptotic factors, more is residual caspase, more PS externalization, higher the likelihood of annexinpositive scan, poorer prognosis and higher necessity for apoptosis inhibition therapy.

\section{Conclusion}

This proof of principle study suggests that Annexin A5 imaging may identify accelerated myocardial cell loss in non-ischemic dilated cardiomyopathy patients with recent worsening of heart failure. Such strategy may offer a new possibility to study interventions aimed at minimizing the progression of myocardial dysfunction. 


\section{REFERENCES}

1. Braunwald E, Bristow MR. Congestive heart failure: fifty years of progress. Circulation 2000; 102:IV14-23.

2. Zhang J, McDonald KM. Bioenergetic consequences of left ventricular remodeling. Circulation 1995; 92:1011-9.

3. Gomez AM, Valdivia $\mathrm{HH}$, Cheng $\mathrm{H}$, et al. Defective excitationcontraction coupling in experimental cardiac hypertrophy and heart failure. Science 1997; 276:800-6.

4. Mani K, Kitsis RN. Myocyte apoptosis: programming ventricular remodeling. J Am Coll Cardiol 2003; 41:761-4.

5. Hirota H, Chen J, Betz UA, et al. Loss of a gp130 cardiac muscle cell survival pathway is a critical event in the onset of heart failure during biomechanical stress. Cell 1999; 97:189-98.

6. Olivetti G, Abbi R, Quaini F, et al. Apoptosis in the failing human heart. N Engl J Med 1997; 336:1131-41.

7. Communal C, Sumandea M, de Tombe P, Narula J, Solaro RJ, Hajjar RJ. Functional consequences of caspase activation in cardiac myocytes. Proc Natl Acad Sci U S A 2002; 99:6252-6.

8. Hayakawa Y, Chandra M, Miao W, et al. Inhibition of cardiac myocyte apoptosis improves cardiac function and abolishes mortality in the peripartum cardiomyopathy of Galpha(q) transgenic mice. Circulation 2003; 108:3036-41.

9. Donath S, Li P, Willenbockel C, et al. Apoptosis repressor with caspase recruitment domain is required for cardioprotection in response to biomechanical and ischemic stress. Circulation 2006; 113:1203-12.

10. Webster KA, Bishopric NH. Apoptosis inhibitors for heart disease. Circulation 2003; 108:2954-6.

11. Fadok VA, Savill JS, Haslett C, et al. Different populations of macrophages use either the vitronectin receptor or the phosphatidylserine receptor to recognize and remove apoptotic cells. J Immunol 1992; 149:4029-35.

12. Martin SJ, Reutelingsperger CP, McGahon AJ, et al. Early redistribution of plasma membrane phosphatidylserine is a general feature of apoptosis regardless of the initiating stimulus: inhibition by overexpression of Bcl-2 and Abl. J Exp Med 1995; 182:1545-56.

13. Hofstra L, Liem IH, Dumont EA, et al. Visualisation of cell death in vivo in patients with acute myocardial infarction. Lancet 2000; 356:209-12.

14. Hofstra L, Dumont EA, Thimister PW, et al. In vivo detection of apoptosis in an intracardiac tumor. Jama 2001; 285:1841-2.

15. Narula J, Acio ER, Narula $N$, et al. Annexin-V imaging for noninvasive detection of cardiac allograft rejection. Nat Med 2001; 7:1347-52. 
16. Chuang ML, Hibberd MG, Salton CJ, et al. Importance of imaging method over imaging modality in noninvasive determination of left ventricular volumes and ejection fraction: assessment by two- and three-dimensional echocardiography and magnetic resonance imaging. J Am Coll Cardiol 2000; 35:477-84.

17. Narula J, Haider N, Virmani R, et al. Apoptosis in myocytes in end-stage heart failure. N Engl J Med 1996; 335:1182-9.

18. Narula J, Pandey P, Arbustini E, et al. Apoptosis in heart failure: release of cytochrome $\mathrm{c}$ from mitochondria and activation of caspase-3 in human cardiomyopathy. Proc Natl Acad Sci U S A 1999; 96:8144-9.

19. Narula N, Narula J, Zhang PJ, et al. Is the myofibrillarlytic myocyte a forme fruste apoptotic myocyte? Ann Thorac Surg 2005; 79:1333-7; discussion 1337.

20. Haider N, Narula N, Narula J. Apoptosis in heart failure represents programmed cell survival, not death, of cardiomyocytes and likelihood of reverse remodeling. J Card Fail 2002; 8:S512-7.

21. Chandrashekhar $Y$, Narula J. Death hath a thousand doors to let out life. Circ Res 2003; 92:710-4.

22. Blankenberg FG, Katsikis PD, Tait JF, et al. Imaging of apoptosis (programmed cell death) with 99mTc annexin V. J Nucl Med 1999; 40:184-91.

23. Narula J, Southern JF, Dec GW, et al. Antimyosin uptake and myofibrillarlysis in dilated cardiomyopathy. J Nucl Cardiol 1995; 2:470-7.

24. Fadok VA, Voelker DR, Campbell PA, Cohen JJ, Bratton DL, Henson PM. Exposure of phosphatidylserine on the surface of apoptotic lymphocytes triggers specific recognition and removal by macrophages. J Immunol 1992; 148:2207-16.

25. Dumont EA, Reutelingsperger CP, Smits JF, et al. Real-time imaging of apoptotic cell-membrane changes at the single-cell level in the beating murine heart. Nat Med 2001; 7:1352-5.

26. Obrador D, Ballester M, Carrio I, Berna L, Pons-Llado G. High prevalence of myocardial monoclonal antimyosin antibody uptake in patients with chronic idiopathic dilated cardiomyopathy. J Am Coll Cardiol 1989; 13:1289-93. 


\section{CHAPTER 3}

\section{Molecular Imaging of Apoptosis and Inflammation for Detection of Infective Endocarditis}


46 CHAPTER 3 
A 54 year old woman presented to our hospital after an episode of fever of unknown origin. The fever had occurred 6 weeks prior to presentation, and subsided spontaneously. The patient had no relevant prior medical history. When presenting to our first aid, she suffered from mild dyspnea. No fever was recorded at the time of presentation. Physical examination revealed normal blood pressure, an elevated central venous pressure, crepitations on both lungs and peripheral edema. In addition, a holosystolic murmur was heard on the apex. Echocardiography was performed, showing mitral regurgitation and a mass attached to the mitral valve (see figure 1A). Blood cultures were taken and an Annexin A5 scan was performed. The bloodcultures showed streptococcus milleri after 9 days of incubation. In spite of adequate antibiotic treatment, patient developed increasing signs of congestive heart failure and was sent for mitral valve replacement after 2 weeks of antibiotics. After surgery valvular tissue was stained for presence of Annexin A5 and macrophages.

Using a dual isotope technique, we were able to localize Annexin A5 uptake in relation to the left ventricle. SPECT showed intense uptake of Annexin A5 in the area of the mitral valve (Figure 1C). The valvular tissue showed abundant Annexin A5 binding. Annexin A colocalized with CD68 staining, a macrophage marker (Figure 1B). The Annexin A5 scan thus predicted infective endocarditis 8 days prior to bloodcultures becoming positive. 

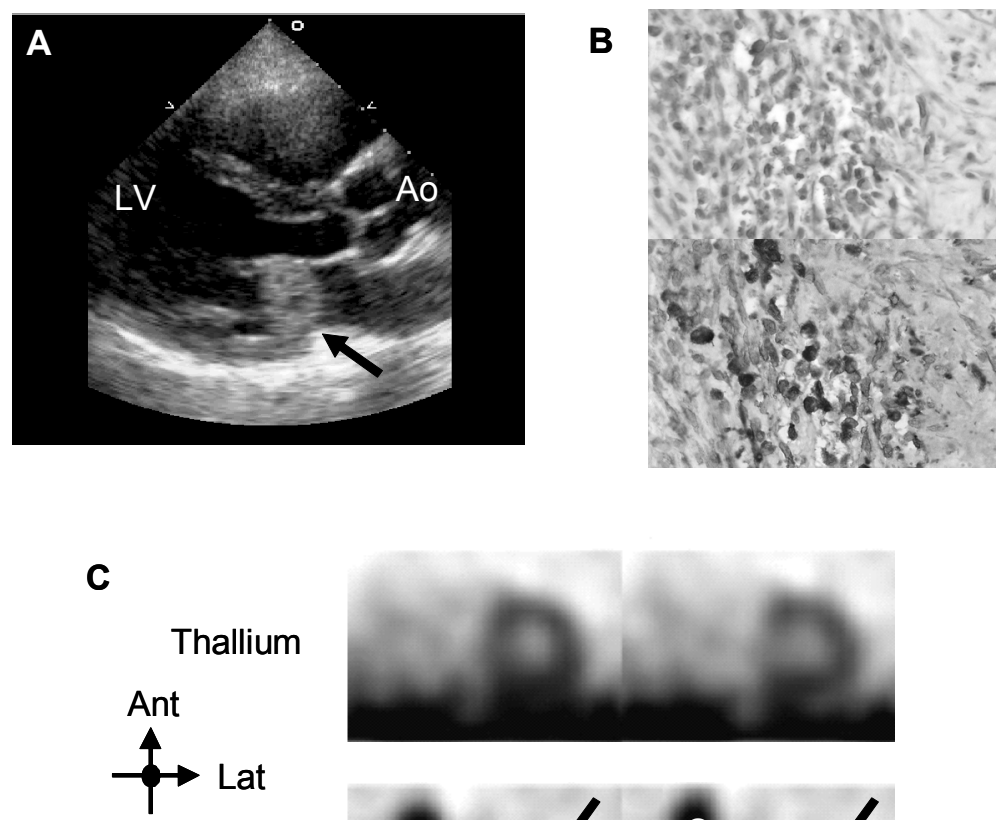

Anx A5

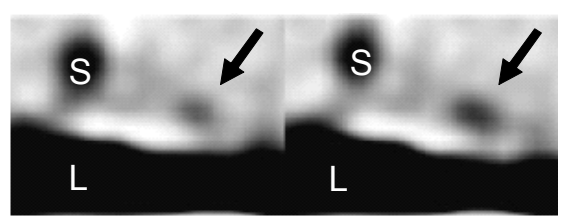

Figure 1:

A: Transthoracal echocardiography, parasternal long axis view of the left ventricle. Arrowhead depicts mass attached to the mitral valve. Ao = Aorta; $L V=$ Left ventricle. B: Immunohistochemistry of the intracardiac mass. Brown staining = Annexin A5. Upper panel shows extensive binding of Annexin A5 to cell membranes. Lower panel shows co-localisation of a macrophage marker (CD68, dark blue staining), and Annexin A5. C: Dual isotope imaging using ${ }^{201} T L$ and ${ }^{99 m} T C$ Annexin A5. Arrowheads point to Annexin A5 uptake in the area of the mitral valve. For full color image see page 94.

\section{DISCUSSION}

Infective endocarditis (IE) remains an important clinical problem, having relatively high morbidity and mortality if not treated aggressively. The incidence rate ranges from 1.7 to 6.2 cases per 100,000 in a general population and has remained essentially unchanged in the last two decades, despite advances in therapy. This can largely be explained by a shift in risk factors predisposing for IE. Novel populations at risk include hemodialysis patients, patients exposed to nosocomial infections, intravenous drug users and increasing incidence of highly sclerotic valves in the elderly patients and increased use of prosthetic valve. These patient groups have all but 
replaced patients with classic risk factors such as rheumatic heart disease. The diagnosis of IE is based on Duke classification, using criteria such as positive bloodcultures, vegetations detected on echocardiography, fever, presence or absence of predisposing heart disease, occurrence of new valvular murmur and signs of distant embolization ${ }^{1}$. Although extremely useful in IE in native valve disease, these criteria have not been evaluated in prosthetic valve IE or IE in hemodialysis patients, hospitalized patients or IV drug users. Hence making the diagnosis of IE is often difficult, but all the more important since early effective treatment prevents tissue destruction and thus improves clinical outcome. Although not present in all cases of IE, valvular destruction often necessitates valvular replacement surgery. Often, timing of valvular surgery is difficult. Although evidence of distant embolization of infective fragments is an indication for early surgery, surgeons prefer insertion of a prosthetic valve in non-infected tissue. Usually, antibiotic treatment is carried on for 6 weeks after diagnosis of IE. Finally, echocardiography cannot reliably differentiate florid vegetations from residual structural changes of the affected valves in cured patients, thereby introducing the risk of unnecessary treatment.

Imaging modalities such as echocardiography or MR can inform us about size, shape and heamodynamic consequences of IE, but are unable to evaluate lesion biology. However, molecular imaging technology can provide biological information. Hence, nuclear imaging techniques have been used for detection of IE. Detection of leukocyte invasion using In111leucocyte scanning has limited sensitivity, rendering it less useful for clinical practise. Gallium-67 is taken up by leucocytes and bacteria. In addition, it may bind to bacterial surface molecules ${ }^{2}$. Gallium SPECT imaging thus may be useful in detecting IE, although no trials have been performed. Inflammation can also be imaged by PET FDG imaging, but cardiac imaging using FDG has the disadvantage of a high background signal. Finally, platelet activation is widely present in IE. This feature has been employed for detection of IE using a radiolabeled gpllb/IIla inhibitor ${ }^{3}$.

We and other groups have shown the use of radiolabeled Annexin A5 imaging in detection of phosphatidylserine (PS) exposure ${ }^{4,5}$. Macrophages involved in phagocytosis expose PS at the site of engulfment of bacteria and cellular fragments ${ }^{6}$. Secondly, activated platelets expose PS to their surface, creating another imaging target ${ }^{7}$. Thirdly, PS is the hallmark of cell undergoing programmed cell death ${ }^{8}$. Programmed cell death is seen in IE at the site of valvular destruction, macrophage apoptosis after engulfment of bacteria and debris and bacterial PCD, thereby creating targets for Annexin A5. We therefore propose that PS exposure is abundant in IE creating a novel opportunity for IE detection using Annexin A5 imaging. 
This case report shows feasibility of detection of PS exposure in IE. AIthough the clinical picture was suggestive of IE, bloodcultures did not show a pathogen up to 9 days. Annexin A5 imaging however, showed uptake of the radiopharmacon on the day of admission. Annexin A5 bound mainly to macrophages, but also to fibroblasts and activated platelets. In conclusion, Annexin A5 imaging may be useful in clinical practise for early diagnosis of IE, evaluation of treatment and timing of surgery, possibly improving outcome. Further studies are needed to assess these questions. 


\section{REFERENCES}

1. Li JS, Sexton DJ, Mick N, et al. Proposed modifications to the Duke criteria for the diagnosis of infective endocarditis. Clin Infect Dis 2000; 30:633-8.

2. Tsan MF. Mechanism of gallium-67 accumulation in inflammatory lesions. J Nucl Med 1985; 26:88-92.

3. Oyen WJ, Boerman OC, Brouwers FM, et al. Scintigraphic detection of acute experimental endocarditis with the technetium-99m labelled glycoprotein IIb/IIla receptor antagonist DMP444. Eur J Nucl Med 2000; 27:392-9.

4. Kietselaer BL, Reutelingsperger CP, Heidendal GA, et al. Noninvasive detection of plaque instability with use of radiolabeled annexin A5 in patients with carotid-artery atherosclerosis. N Engl J Med 2004; 350:1472-3.

5. Hofstra L, Dumont EA, Thimister PW, et al. In vivo detection of apoptosis in an intracardiac tumor. Jama 2001; 285:1841-2.

6. Callahan MK, Williamson P, Schlegel RA. Surface expression of phosphatidylserine on macrophages is required for phagocytosis of apoptotic thymocytes. Cell Death Differ 2000; 7:645-53.

7. Stratton JR, Dewhurst TA, Kasina S, et al. Selective uptake of radiolabeled annexin $\mathrm{V}$ on acute porcine left atrial thrombi. Circulation 1995; 92:3113-21.

8. Fadok VA, Voelker DR, Campbell PA, Cohen JJ, Bratton DL, Henson PM. Exposure of phosphatidylserine on the surface of apoptotic lymphocytes triggers specific recognition and removal by macrophages. J Immunol 1992; 148:2207-16. 


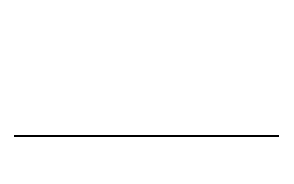




\section{Non-invasive detection of plaque instability using radiolabeled Annexin-A5 in patients with atherosclerotic carotid artery disease}

Bas L.J.H. Kietselaer, Chris P.M. Reutelingsperger, Guido A.K. Heidendal, Werner Mess, Jan Tordoir, Leo Hofstra, Hein J.J. Wellens and Jagat Narula.

Published in different format in:

Noninvasive detection of plaque instability with use of radiolabeled annexin A5 in patients with carotid-artery atherosclerosis. New England Journal of Medicine 2004; 350:1472-3.

ACST: which subgroups will benefit most from carotid endarterectomy? Lancet 2004; 364:1124-5; author reply 1125-6. 
54 CHAPTER 4 


\section{INTRODUCTION}

Although the progressive stenosis of the arterial lumen constitutes the basis of ischemic symptoms in atherosclerotic vascular disease, the acute vascular events are not necessarily associated with severely occlusive lesions ${ }^{1}$. In up to two-thirds of the patients with acute coronary syndromes, the acute event results from plaque rupture and formation of an occlusive thrombus ${ }^{2}$. Vulnerability of the atherosclerotic plaque to rupture is associated with distinct histopathologic characteristics including large lipid core, attenuated fibrous cap and inflammatory cell infiltration of the cap ${ }^{3}$. It is being increasingly recognized that apoptosis of various cellular components in atherosclerotic plaques contributes to plaque vulnerability. Apoptosis of smooth muscle cells leads to progressive thinning of fibrous cap, and that of macrophages leads to enlargement of lipid core ${ }^{4}$. Also, apoptosis of macrophages in the fibrous cap has been causally linked to plaque rupture ${ }^{5}$.

Several diagnostic methods have attempted to evaluate unstable plaques. Such techniques include MRI detection of thin fibrous caps and that of ferrous oxide particle-rich macrophage-population or detection of inflammatory foci in plaques by thermography catheters. We have previously demonstrated that apoptosis can be imaged non invasively in experimental atherosclerotic plaques using radiolabeled Annexin-A5 ${ }^{6,7}$. Annexin-A5 is plasma protein, which shows strong affinity for phosphatidyl serine, exposed by apoptotic cells. In the present study, we investigated the feasibility of clinical utility of Annexin imaging in 3 patients with 3-day to 3-month old transient ischemic attacks (TIA), who were scheduled for carotid endarterectomy.

\section{METHODS}

Four patients that were scheduled for carotid endarterectomy were imaged one to three days prior to surgery using ${ }^{99 \mathrm{~m}} \mathrm{Technetium}\left({ }^{99 \mathrm{~m}} \mathrm{Tc}\right)$ labeled Annexin A5 (Theseus Imaging Corporation, Boston, MA). All patients had suffered from a transient ischaemic attack (TIA) due to an atherosclerotic lesion in their internal carotid artery. Of the four cases, two had suffered from a TIA in their right hemisphere 3 and 4 days prior to imaging, respectively. The other two cases had experienced symptoms 3 months prior to surgery. All patients received a dose of 600 to $800 \mathrm{MBq}$ of ${ }^{99 \mathrm{~m}} \mathrm{Tc}$ labeled Annexin A5. Patients were imaged 6 hours after infusion of labeled Annexin A5, using a multiSPECT dual head gamma camera (Siemens, Hoffman Estate, IL); 64 angled views were obtained for 60 seconds each. Data were reconstructed using a back projection method by means of a butterworth filter. Before surgery, a Doppler-ultrasound study was performed. The endarter- 
ectomy specimens retrieved during surgery were embedded and stained by H\&E and Movat's pentachrome stains. Direct immunohistochemical staining was performed to localize the binding of Annexin A5.

\section{RESULTS}

Two patients who had suffered from a recent TIA showed distinct uptake of radiolabeled Annexin in the area of the right carotid artery lesion; the area of uptake corresponded to the ultrasonically verified stenotic lesion. Interestingly, preoperative Doppler-ultrasound study in one patient with recent symptoms had demonstrated similar degree of stenosis in the contralateral carotid artery, but no Annexin uptake was observed (Figure 1A). The two cases that had sustained TIA 3 months prior to imaging showed no uptake in the carotid artery on the affected side (Figure 1B). Doppler ultrasound had showed significant stenoses in these two patients. Analysis of endarterectomy specimen from the patients with positive imaging results showed unstable plaque morphology, including a thin fibrous cap that harbored significant macrophage infiltration. On immunohistochemical analysis, Annexin binding was predominantly observed on the cell membranes of macrophages at the shoulder of the unstable plaque; some staining was also seen in fibroblasts and vascular smooth muscle cells (Figure 1C). The endarterectomy specimens from the two patients with remote TIA and no Annexin uptake revealed thick fibrous caps and a small lipid core in their atherosclerotic plaques indicating stable plaque characteristics; no Annexin binding was observed, as shown in figure $1 \mathrm{D}$. 
Recent TIA

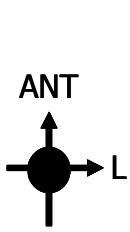

A

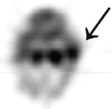

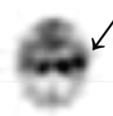

Transverse

C
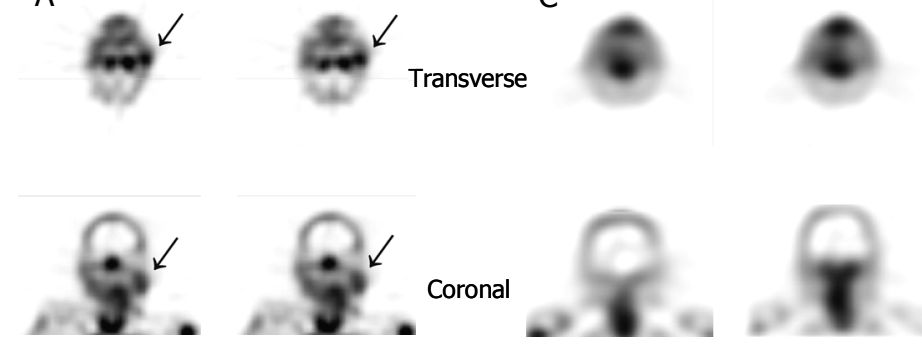

\section{B}

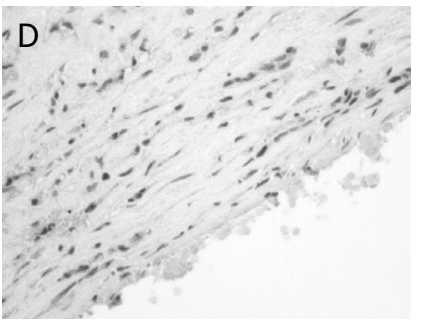

Figure 1:

Annexin A5 imaging of carotid artery atherosclerosis. Panel A: Annexin imaging in a patient with recent TIA. Note enhanced uptake in the left carotid artery region (arrowheads). Panel B: Unstable atherosclerotic plaque and Annexin binding to cell membranes, mainly macrophages. Panel C: Annexin imaging in remote TIA, no enhanced uptake is observed. Panel D: Stable atherosclerotic plaque, absence of Annexin A5 binding to cells. For full color image see page 95.

\section{DISCUSSION}

This preliminary study for the first time demonstrates the feasibility of identification and localization of unstable carotid artery lesions in patients with targeted molecular imaging technology. In the patient with recent TIA, high Annexin uptake on SPECT imaging suggests the presence of unstable plaque. Immunohistochemical analysis revealed Annexin uptake within the macrophage infiltration in atherosclerotic plaques. In the same patient, a similar degree of carotid artery stenosis on the contralateral (unaffected) side did not show any Annexin uptake. In addition to the feasibility of concept of imaging vulnerable atherosclerotic plaque, the study reaffirms that the vascular wall biology of an atherosclerotic lesion is the major determinant of vulnerability rather than the degree of stenosis. In addition, localization of Annexin within the macrophages subjacent to thin fibrous cap further supported the inflammatory hypothesis of plaque rupture ${ }^{5}$. In the two negative cases, there was a delay of 3 months between the TIA and the imaging or surgical intervention. Histopathological analysis of these 
specimens demonstrated stable plaque morphology consonant with negative Annexin SPECT images. These data suggested that the cell death in the plaque was no longer present, which may indicate stabilization of the lesion. Experimental studies have demonstrated that the statin therapy decreases the Annexin determined prevalence of apoptosis in atherosclerotic plaques by approximately one-half. However, since statins may take at least 4 weeks for efficacy in the plaque stabilization ${ }^{8}$, one might speculate that intervention in the cell death program to prevent macrophage apoptosis may offer a novel approach to stabilization of the atherosclerotic lesions in acute phase. Thus this study opens a new avenue of diagnostic imaging modality in unstable plaques, and provides a basis for provocative therapeutic strategy in the management of acute vascular event. 


\section{REFERENCES}

1. Lammie GA, Sandercock PA, Dennis MS. Recently occluded intracranial and extracranial carotid arteries. Relevance of the unstable atherosclerotic plaque. Stroke 1999; 30:1319-25.

2. Dirksen MT, van der Wal AC, van den Berg FM, van der Loos CM, Becker AE. Distribution of inflammatory cells in atherosclerotic plaques relates to the direction of flow. Circulation 1998; 98:2000-3.

3. Depre C, Wijns W, Robert AM, Renkin JP, Havaux X. Pathology of unstable plaque: correlation with the clinical severity of acute coronary syndromes. J Am Coll Cardiol 1997; 30:694-702.

4. Isner JM, Kearney M, Bortman S, Passeri J. Apoptosis in human atherosclerosis and restenosis. Circulation 1995; 91:2703-11.

5. Kolodgie FD, Narula J, Burke AP, et al. Localization of apoptotic macrophages at the site of plaque rupture in sudden coronary death. Am J Pathol 2000; 157:1259-68.

6. Kietselaer BLJH, Thimister PW, Reutelingsperger CPM, et al. Molecular imaging of cell death in intracardiac tumours. Netherlands Heart Journal 2002; 10:313-7.

7. Hofstra L, Liem IH, Dumont EA, et al. Visualisation of cell death in vivo in patients with acute myocardial infarction. Lancet 2000; 356:209-12.

8. Zhao XQ, Yuan C, Hatsukami TS, et al. Effects of prolonged intensive lipid-lowering therapy on the characteristics of carotid atherosclerotic plaques in vivo by MRI: a case-control study. Arterioscler Thromb Vasc Biol 2001; 21:1623-9. 


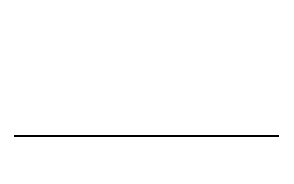




\section{CHAPTER 5}

\section{The diagnosis of intracardiac masses: absence of Annexin A5 uptake indicates favorable prognosis.}

Bas L.J.H. Kietselaer; Maarten J.M. Cramer; Jagat Narula;Navneet Narula; Ing Han Liem; Hendrikus H Boersma; Marie-Therese Pakbiers,Chris P.M. Reutelingsperger; Guido A.K. Heidendal; Harry J.G.M. Crijns; Leonard Hofstra.

Published in part in:

Molecular imaging of cell death in intracardiac tumors. Netherlands Heart Journal 2002; 10:313-7.

Submitted for review 


\section{ABSTRACT}

Purpose: Endocardial masses pose a diagnostic dilemma. Prognosis and treatment greatly depend on the biological nature of the mass. Due to high risk of embolic complications, biopsy taking from intracardiac masses is clinically not employed. Current imaging technology can depict size, shape and location, but fails to differentiate benign from malignant intracardiac masses.

Experimental Design: We evaluated 15 consecutive cases presenting to our department with an unknown cardiac mass. All patients were subjected to SPECT imaging using radiolabeled Annexin A5. 8 Patients were operated upon, enabling diagnosis by histology. Patients in whom surgery was not an option underwent follow-up echocardiography.

Results and conclusions: Eleven patients with a negative scan showed either benign tumor at surgery or no growth at three years follow up. Negative Annexin A5 scans were therefore associated with a favourable outcome. Positive scans showed malignant tumor, endocarditis or fresh intracavitary thrombus, associating Annexin A5 positivity with poor outcome. These data indicate that Annexin A5 imaging may have incremental diagnostic value in patienst presenting with an unknown intracardiac mass. 


\section{INTRODUCTION}

Intracardiac masses are not too commonly seen ${ }^{1}$. They may, however, have dire consequences. The diagnosis of these masses has been based on their echocardiographically defined location, mobility and appearance. These masses often comprise tumors, thrombi and infectious processes. Subsets of these lesions may have significantly poor outcome such as that associated with fresh unorganized thrombi, malignant tumors and infected vegetation. Therefore, in addition to an anatomical diagnosis, it is important to obtain biological characteristics. Most patients presenting with a tumor in one of the intra-cardiac cavities turn out to have a metastatic tumor. The incidence of primary cardiac tumors is difficult to assess, but post-mortem studies indicate that $0.01 \%$ to $0.3 \%$ of patients have an intracardiac tumor at autopsy $^{2,3}$. Malignant cardiac tumors comprising between 5.5 to $10 \%$ of all primary cardiac tumors in surgical studies ${ }^{1,2}$. In autopsy studies, up to $25 \%$ of primary cardiac tumors are malignant ${ }^{1,2,4-6}$. Malignant primary cardiac tumors are sarcomas in more than $95 \%$ of the cases, of which angiosarcoma is the most common. Whereas benign intracardiac tumors carry an excellent survival rate, malignant intracardiac tumors have a very poor prognosis. Finally, a fresh left ventricular thrombus developing in the context of a poor LV function, carries a high risk of thromboembolic complications. Thus, obtaining information on the nature of the intra-cardiac mass prior to medical treatment or surgery is imperative to define the best therapeutic strategy in an individual patient.

Conventional techniques such as echocardiography, CT or MRI give insight in the anatomy of cardiac tumors. However, they do not reveal biological information about these tumors, such as the benign or malignant makeup. Thus, making a definite diagnosis is often difficult if not impossible to make until histological examination of the resected tumor has been performed ${ }^{8}$, since biopsy taking of an intracardiac mass carries a high risk of embolic complications. Only in selected cases a biopsy of a metastatic skin lesion will reveal the nature of the intra-cardiac mass.

Non-invasive biological imaging such as positron emission tomography of ${ }^{18}$ Fluordeoxyglucose (PET-FDG) has been used to assess the nature of tumors, discriminating malignant tumors by the amount of glucose metabolism. The disadvantage of the use of PET imaging to identify intracardiac lesions is hampered by the high background signal in cardiac imaging. An alternative strategy to obtain information on the biology of intra-cardiac tumors is to make use of targeted imaging agents. Annexin A5 binds to phosphatedylserine (PS) which is exposed by the cell membrane of cells undergoing programmed cell death ${ }^{9}$. Our group and others have shown the clinical use of radiolabeled Annexin A5 in detecting programmed cell death ${ }^{10,11}$. One of the biological differences between malig- 
nant and benign lesions is the rate of cell death ${ }^{12}$. Histo-pathological studies have shown that the extent of cell death in a tumor increases with the rate of malignancy. We previously showed feasibility of detecting cell death in an intracardiac malignant tumor ${ }^{13}$. Finally, Annexin A5 can be used for detection of fresh intracavitary thrombus in animals ${ }^{15}$. We hypothesize that molecular imaging using radiolabeled Annexin A5 allows non-invasive assessment of the biology of intracardiac masses in patients, and, therefore, supports diagnosis and management of therapy.

\section{MATERIALS AND METHODS}

\section{Patient characteristics}

We evaluated 15 patients with an unknown intracardiac mass tumors who presented to our and 3 referring centers within the period of one year. Age ranged from 15 to 92 years. In all cases the diagnosis of an intracardiac mass was made by echocardiographic analysis. Patient characteristics are presented in table 1. Some patients were not operated upon due to various reasons, all stated in table 1 . If a patient is classified inoperable, this indicates a clinical status too poor for cardiac surgery because of concomitant disease. This study was carried out in accordance to the declaration of Helsinki. All patients signed informed consent. The study was approved by the university hospital of Maastricht ethical committee.

\section{Non invasive imaging with 99mTechnetium labeled Annexin A5}

Patients referred for cardiac surgery were imaged the day prior to surgery. Human recombinant Annexin A5 was labeled with 900 to $1000 \mathrm{MBq}$ ${ }^{99 m}$ Technetium $\left({ }^{99 m} \mathrm{Tc}\right)$ using a Hynic bridge (Apomate, Theseus Imaging Corporation, Boston, MA, USA). Radiochemical purity varied from 90 to 97 percent. The labeled Annexin A5 was infused 4-6 hours prior to imaging. 30 Minutes prior to imaging, 60 to $65 \mathrm{MBq}{ }^{201}$ Thallium $\left({ }^{201} \mathrm{TI}\right)$ was infused. Scintigraphic imaging was done using a multiSPECT 2 gamma camera (Siemens, Hoffman Estate, IL, USA). A dual isotope imaging protocol was used, acquiring the ${ }^{99 \mathrm{~m}} \mathrm{Tc}$ and ${ }^{201} \mathrm{TI}$ data simultaneously. We used an energy peak of $140 \mathrm{keV}$ with a window of $10 \%$ for the ${ }^{99 \mathrm{~m}} \mathrm{Tc}$ data. For the ${ }^{201} \mathrm{TI}$ data an energy peak of $60 \mathrm{keV}$ with a window of $10 \%$ and a peak of $167 \mathrm{keV}$ and a window of $15 \%$ were chosen. We used a 64 by 64 matrix and 64 angle views, counting each angle for 60 seconds. Studies were reconstructed using a back projection method by means of a Butterworth filter with a cutoff frequency of 0,55 and an order of 5 . Standard views of the left ventricle were reconstructed using the ${ }^{201} \mathrm{Tl}$ dataset. The ${ }^{99 \mathrm{~m}} \mathrm{Tc}$ dataset was reconstructed in using the same limits and orientation, which allowed us to relate the possible Annexin A5 uptake to the position of the left ventricle. One patient was imaged using a SPECT/CT device in a referring hospital (Infinia 
Hawkeye; GE healthcare, Waukesha, WI, USA). A similar dose, timing and energy settings were used for the SPECT images of radiolabeled Annexin A5. The CT images were used for anatomic reference. Fusion of the Annexin A5 dataset onto the CT images enabled localization of Annexin A5 uptake. Images were assessed by two blinded observers (IL, GH).

Histopathologic and immunohistochemical analysis of specimens Surgical removal of the intracardiac mass was performed in 8 cases. Tissue was obtained from all these excised masses and embedded. All tissue sections were characterized using standard H\&E (hematoxiclin-eosin) staining and anti Annexin A5 staining as described previously ${ }^{16}$, using polyclonal anti-annexin A5 rabbit antibody (Hyphen Biomed).

\section{RESULTS}

In 14 out of 15 patients the intracardiac mass was diagnosed using echocardiography. Typical examples of the echocardiographic presentation of an intra-cardiac mass are found in figure 1, panels IA trough IC. In the remaining patient the diagnosis was done by means of SPECT/CT imaging, as shown in figure 2. Of the entire group of patients $(n=15)$, eleven patients showed a negative Annexin A5 scan. A typical example is shown in figure 1, panel IB. Six of the patients with a negative scan were operated upon. Histology showed typical myxoma in all 6 cases, such as shown in figure 1, panel IC. The presence of clustering of nuclei and a large extent of extracellular matrix are diagnostic for cardiac myoxoma. Immonuhistochemistry showed a very low number $(<0.01 \%)$ of cells binding Annexin to their cell surface. The remaining five cases with a negative Annexin A5 SPECT patients did not undergo surgery, and were followed by repeat echocardiography. No increase in size or embolic complications were seen during a mean follow-up of 3 years (range 2 to 5.2 years). 

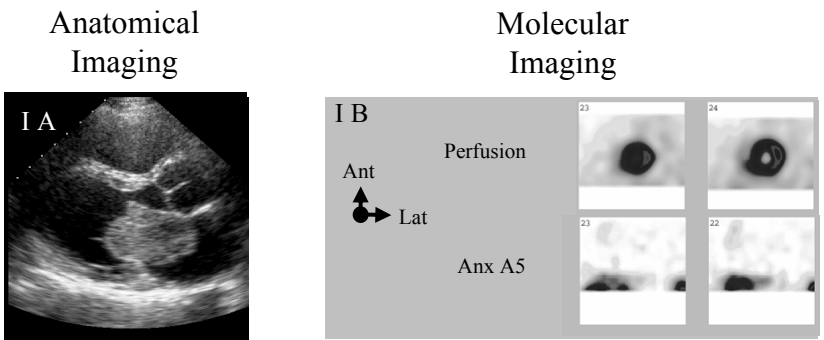

\section{Histology}
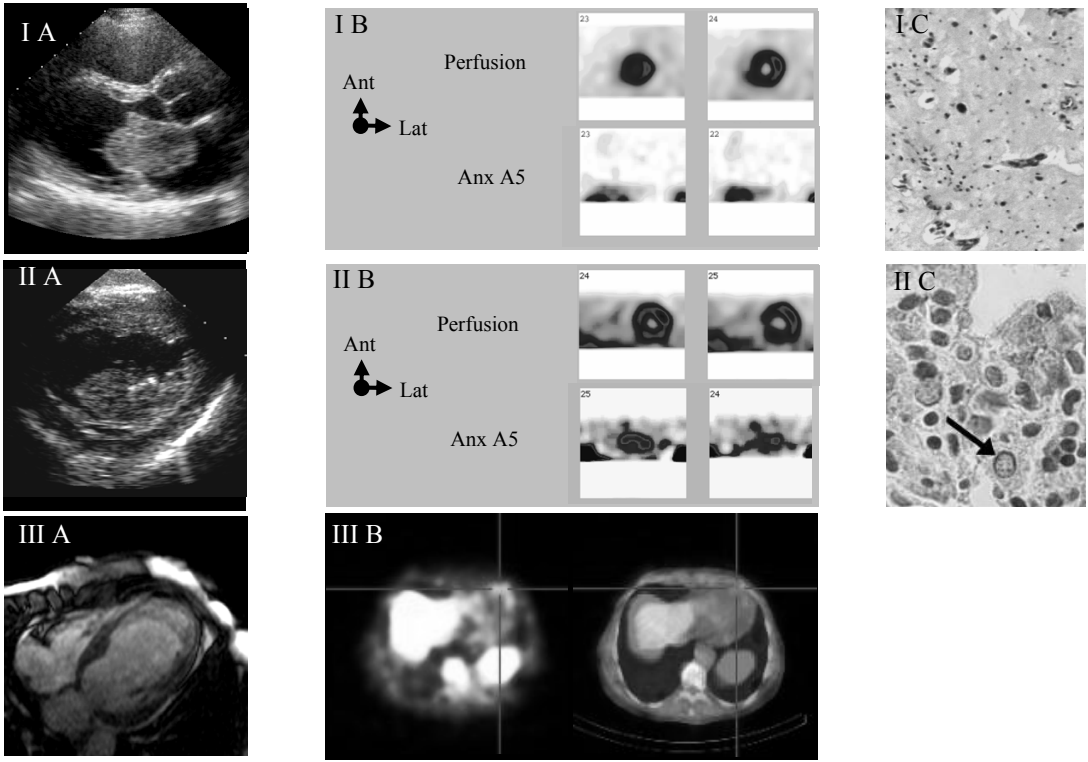

Figure 1:

Molecular and anatomical imaging of intracardiac masses.

Panel IA shows a parasternal long axis view of the left ventricle. There is a clear intracardiac mass shown in the area of the mitral valve. Panel IB shows a normal perfusion image of the left ventricle (short axis view). Note the absence of uptake of annexin A5 in the same region. Panel IC shows histology, no Annexin A5 staining was observerd.

Panel IIA shows a parasternal long axis view of the left ventricle with a large mass attached to the left ventricular wall. Panel IIB shows intense uptake of radiolabeled Annexin A5 in the region of the left ventricle. Panel IIC confirms binding of annexin A5 to cells (brown staining). Histology showed sarcoma

Panel IIIA is a cardiac magnetic resonance image. This four chamber view shows a large mass attached to the LV apex in the presence of an apical infarct. Panel IIIB shows uptake of radiolabeled Annexin in the area of the LV apex in the left panel. Right panel shows a fusion image between low resolution CT and nuclear imaging, confirming the localization of the Annexin uptake (LV apex). In this case no cardiac surgery was performed. For full color image see page 96.

Three patients showed uptake of ${ }^{99 \mathrm{~m}} \mathrm{Tc}$ labeled Annexin A5 within the area of the left ventricle. A typical example is shown in figure 1, panels IIB and IIC. Two of these patients were operated upon. In one of the positive patients, slight complaints and near collaps were present. In this case, echocardiography showed a large mass in the left ventricular cavity (Figure 1; panel IIA). The histologic analysis of the surgically removed tumor specimen showed undifferentiated sarcoma. In addition, staining for Annexin A5 was performed, showing abundant binding of Annexin A5 to the plasma membranes of tumor cells (Figure 1; panel IIC). A further positive scan was 
made in a patient that had suffered a large anterior wall myocardial infraction prior to presentation. Echocardiography showed very slow flow in the left ventricular apex, and a mass with a broad base attached to infarcted myocardium. MRI also showed a left ventricular mass at the apex (Figure 1 panel IIIA). SPECT/CT imaging displayed uptake of radiolabeled Annexin in the left ventricular apex (Figure 1, panel IIIB). Finally, one patient (pt \#1) with an intracardiac mass arrived in our hospital in severe cardiac failure due to obstruction of almost the entire right atrium by tumor mass. She was referred for emergency surgery. PA diagnosis showed osteosarcoma, and abundant binding of native (endogenous) Annexin A5 to tumor cells. The extent of binding and size of the tumor was similar to that of patient \#3.

On immunohistochemical analysis, the apoptotic index (cells expressing PS/ total number of cells) was below 0.01 in the tumor specimens of patients with a negative Annexin A5 SPECT. The apoptotic index was above 0.4 ( 0.41 and 0.52 , respectively) in the two patients with a positive SPECT with a primary malignant intracardiac mass. In our dataset, the apoptotic index correlated well with degree of malignancy.

Panel IIIA shows MRI image of the left ventricle. Note the large mass attached to the left ventricular apex. Panel IVB shows uptake of radiolabeled Annexin A5 at the area of the left ventricular apex. The image on the right shows fusion of the MRI data with the Annexin A5 SPECT data, confirming that the uptake is localized at the left ventricular apex. No surgery was required in this patient.

\section{DISCUSSION}

Our data indicate that molecular imaging, using radiolabeled Annexin A5, is feasible and safe in patients presenting with an unknown intracardiac mass. The imaging results correlate well with Annexin A5 binding to cells on histology. More importantly, we show that absence of uptake Annexin A5 uptake in the intra-cardiac mass as found on SPECT imaging, indicates a benign origin of the intracardiac lesions. In all patients with a negative Annexin A5 SPECT scans in whom the intracardiac mass was surgically removed histologic examination showed the typical features of myxoma. In patients with a negative Annexin A5 SPECT in whom surgery was not performed, no growth of the intra-cardiac lesion was observed and complete absence of complications during 3 year follow-up. Taken together, these data indicate that a negative Annexin A5 SPECT is strongly associated with favorable outcome in patients with unknown intracardiac masses. 
Positive scans were seen in patients with malignant intracardiac tumor and fresh intracavitary thrombus. In malignant tumors, Annexin A5 binds to apoptotic cells externalizing phosphatidylserine (PS). This is in accordance with the literature, as it has been reported that a higher rate of programmed cell death in tumors correlates with more aggressive tumors and rapid metastasis ${ }^{12}$. Secondly, Annexin A5 bound to externalized PS in fresh thrombus. Rapid PS exposure is seen in platelets stimulated by thrombin and collagen ${ }^{18,19}$. Exposed PS is essential for assembly of active prothrombinase $^{20}$, and plays a role in activation of prothrombin ${ }^{21}$. Detection of PS exposure has been used to detect fresh cloth in porcine left atrial thrombus ${ }^{15}$.

These data confirm feasibility of studying biology of masses not suitable for biopsy taking. Moreover, Annexin A5 imaging can be performed using widely available SPECT technology. In contrast with PET- ${ }^{18} \mathrm{FDG}$, Annexin A5 imaging does not suffer from high background radiation in the area of the heart, improving image quality and ease of interpretation in this area. Potentially the response of masses to treatment could be monitored using a sequential imaging approach, as has been suggested in trials evaluating success of treatment in non-Hodgkin lymphoma ${ }^{22}$, providing additional information in areas with high PET background noise. This new technique of molecular imaging of programmed cell death may prove to be a valuable addition to the more conventional non-invasive techniques, and can provide important clues as to the nature of the mass. Due to the low number of patients, our study is insufficiently powered for stating that positive scans are always indicative of malignancy. We conclude that patients with an intracardiac mass and a positive Annexin A5 SPECT should undergo an aggressive diagnostic and therapeutic approach. Furthermore, patients with a positive Annexin A5 SPECT and absence of fever or conditions enabling thrombus formation, malignancy should be suspected. 


\section{REFERENCES}

1. Blondeau P. Primary cardiac tumors--French studies of 533 cases. Thorac Cardiovasc Surg 1990; 38 Suppl 2:192-5.

2. Reynen K. Frequency of primary tumors of the heart. Am J Cardiol 1996; 77:107.

3. McAllister HA FJ. Tumors of the cardiovascular system. In: Hartmann WH CW, ed. Atlas of tumor pathology. Washington DC: Armed Forces Institute of pathology, 1978.

4. Centofanti P, Di Rosa E, Deorsola L, et al. Primary cardiac tumors: early and late results of surgical treatment in 91 patients. Ann Thorac Surg 1999; 68:1236-41.

5. Molina JE, Edwards JE, Ward HB. Primary cardiac tumors: experience at the University of Minnesota. Thorac Cardiovasc Surg 1990; 38 Suppl 2:183-91.

6. Perchinsky MJ, Lichtenstein SV, Tyers GF. Primary cardiac tumors: forty years' experience with 71 patients. Cancer 1997; 79:1809-15.

7. Li JS, Sexton DJ, Mick N, et al. Proposed modifications to the Duke criteria for the diagnosis of infective endocarditis. Clin Infect Dis 2000; 30:633-8.

8. Rienmuller R, Tiling R. MR and CT for detection of cardiac tumors. Thorac Cardiovasc Surg 1990; 38 Suppl 2:168-72.

9. Fadok VA, Bratton DL, Rose DM, Pearson A, Ezekewitz RA, Henson PM. A receptor for phosphatidylserine-specific clearance of apoptotic cells. Nature 2000; 405:85-90.

10. Hofstra L, Liem IH, Dumont EA, et al. Visualisation of cell death in vivo in patients with acute myocardial infarction. Lancet 2000; 356:209-12.

11. Kietselaer BL, Reutelingsperger CP, Heidendal GA, et al. Noninvasive detection of plaque instability with use of radiolabeled annexin A5 in patients with carotid-artery atherosclerosis. N Engl J Med 2004; 350:1472-3.

12. Naresh KN, Lakshminarayanan K, Pai SA, Borges AM. Apoptosis index is a predictor of metastatic phenotype in patients with early stage squamous carcinoma of the tongue: a hypothesis to support this paradoxical association. Cancer 2001; 91:578-84.

13. Hofstra L, Dumont EA, Thimister PW, et al. In vivo detection of apoptosis in an intracardiac tumor. Jama 2001; 285:1841-2.

14. Kietselaer BL, Narula J, Hofstra L. The Annexin code: revealing endocarditis. Eur Heart J 2007:948.

15. Stratton JR, Dewhurst TA, Kasina $S$, et al. Selective uptake of radiolabeled annexin $V$ on acute porcine left atrial thrombi. Circulation 1995; 92:3113-21. 
16. Dumont EA, Hofstra L, van Heerde WL, et al. Cardiomyocyte death induced by myocardial ischemia and reperfusion: measurement with recombinant human annexin- $\mathrm{V}$ in a mouse model. Circulation 2000; 102:1564-8.

17. Callahan MK, Williamson $P$, Schlegel RA. Surface expression of phosphatidylserine on macrophages is required for phagocytosis of apoptotic thymocytes. Cell Death Differ 2000; 7:645-53.

18. Williamson P, Bevers EM, Smeets EF, Comfurius P, Schlegel RA, Zwaal RF. Continuous analysis of the mechanism of activated transbilayer lipid movement in platelets. Biochemistry 1995; 34:10448-55.

19. Dillon SR, Mancini M, Rosen A, Schlissel MS. Annexin V binds to viable $B$ cells and colocalizes with a marker of lipid rafts upon B cell receptor activation. J Immunol 2000; 164:1322-32.

20. Comfurius P, Senden JM, Tilly RH, Schroit AJ, Bevers EM, Zwaal RF. Loss of membrane phospholipid asymmetry in platelets and red cells may be associated with calcium-induced shedding of plasma membrane and inhibition of aminophospholipid translocase. Biochim Biophys Acta 1990; 1026:153-60.

21. Zhai X, Srivastava A, Drummond DC, Daleke D, Lentz BR. Phosphatidylserine binding alters the conformation and specifically enhances the cofactor activity of bovine factor $\mathrm{Va}$. Biochemistry 2002; 41:5675-84.

22. Kartachova M, Haas RL, Olmos RA, Hoebers FJ, van Zandwijk N, Verheij $M$. In vivo imaging of apoptosis by $99 \mathrm{mTc}$-Annexin $\mathrm{V}$ scintigraphy: visual analysis in relation to treatment response. Radiother Oncol 2004; 72:333-9. 
CHAPTER 6

General discussion 
72 CHAPTER 6 
Clinical syndromes such as the acute coronary syndrome, stroke or development of congestive heart failure are often the first manifestation of cardiovascular disease in previously asymptomatic patients. These patients have suffered from subclinical disease prior to clinical events. Identification of patients at risk for these syndromes is therefore an important goal in clinical medicine ${ }^{1}$. In addition to classical risk factors, it has become increasingly clear that insight into molecular mechanisms leading up to these clinical syndromes can help identify high risk patients. In addition, intervention in such mechanisms can aid in preventing such events from occurring. Finally, monitoring these biological mechanisms may aid in evaluating success of treatment, or warrant a more aggressive treatment strategy. In recent years, measuring biomarkers in serum such as high sensitive Creactive protein ${ }^{2,3}$ and $\mathrm{N}$-terminal pro-brain natriuretic peptide ${ }^{4}$ has complemented classical risk factors in identification of patients at risk. Although useful to further risk-stratify patients, their incremental value to predict major cardiac events is limited ${ }^{5}$.

Serum markers define the state of the organism, but fail to identify the anatomical site and extent of the problem. Such information could be useful when aggressive, invasive treatment strategies are employed. As described in the introduction of this thesis, molecular imaging can identify extent, localization and timing of biological events leading up to clinical syndromes. In this thesis, we have shown feasibility of molecular imaging of PS expression to detect biological events leading up to, or contributing to, clinical syndromes.

Feasibility of PS expression detection and its correlation to infarct size has been shown in patients with acute myocardial infarction ${ }^{6,7}$. In such events there is abundant PS expression due to large amounts of cell loss in a short timeframe. A similar abundance of PS expression is seen in apoptosis of endocardial tumors, where large amounts of cells express PS to their surface, as shown in chapter six. Finally, the same holds true for PS expression detection in infective endocarditis, as the tissue sections express extensive Annexin A5 binding to macrophages ${ }^{8}$. However, most molecular events occur at lower rates. Nevertheless, their continuous character bestows them with a profound impact on the organism.

\section{APOPTOSIS IN HEART FAILURE: A DELICATE BALANCE}

The role of programmed cell death in heart failure has been studied extensively by our group and others. Although it was previously believed that activation of the cell death program in heart failure patients leads to demise of the cardiomyocyte, new insights are developing. Multiple roles have 
been found for various regulating proteins. For instance, animal models of receptor mediated activation or moderate (4-fold) overexpression of Gaq can induce hypertrophy, whereas high expression levels of Gaq and stress due to pregnancy ${ }^{9}$ or pressure overload ${ }^{10}$ induces marked left ventricular dilatation and a high number of apoptotic myocytes. Administration of a polycaspase inhibitor rescues part of the phenotype and improves survival $^{11}$. GP130 mediated signaling of cytokines can produce hyperthrophy due to activation of certain kinases which in turn activate genes that are involved in cardiac hypertrophy ${ }^{12}$. GP130 provides a protective role for cardiomyocytes during cytokine release, as conditional knockout of the gene and pressure overload induces massive apoptosis and dilatation of the left ventricle in mice ${ }^{13}$. Calcium overload may produce hyperthrophy via calcineurin signalling ${ }^{14}$, but calcium overload, may also trigger cytochrome $\mathrm{C}$ release and cause demise of the cell due to apoptosis. Thus it seems that there is a delicate balance of signals in heart failure causing compensatory effects of the myocardium to stress. If stress is increased over a certain level, apoptotic signaling sets in.

Interestingly, activation of caspases not necessarily causes demise of cells. PCD does contribute to slowly progressive myocardial dysfunction in heart failure $^{15}$. Cytokinemia and ischemic/oxidative stress lead to release of cytochrome $\mathrm{C}$ from the mitochondria into the cytoplasmic compartment and this leads to activation of caspase $3^{16}$. Active caspase 3 cleaves the contractile proteins and activates DNA fragmentation enzymes. The loss of cytochrome $\mathrm{C}$ signifies the loss of energy production mechanism in mitochondria. Fragmentation of contractile proteins contributes to decline in left ventricular function. As described in the introduction, activation of caspase 3 results in expression of PS. However, several protective steps inhibit DNA cleavage by inhibition of active caspase 3 fragments. These include upregulation of $\mathrm{Bcl} 2-{ }^{14}$ and XIAP like proteins ${ }^{17}$. Interrupting the apoptotic process creates a mechanism of programmed cell survival ${ }^{18-20}$. Recently, apoptosis-inducing factor (AIF) has shown to function as a mitochondrial anti-oxidant in a murine model of heart failure. Mice deficient of AIF show increased susceptibility to pressure induced heart failure ${ }^{21}$. Furthermore, addition of anti-oxidants in mice deficient of AIF prevented apoptosis and necrosis and partially rescued the phenotype ${ }^{22}$. Another balance is set, between anti- and pro-apoptotic signalling.

The amount of programmed cell death in heart failure has been studied by our group ${ }^{16}$ and others. Olivetti et al quantified apoptosis in explanted cardiomyopathic hearts. They show a prevalence of $0.05 \%$ to $0.1 \%$ apoptotic myocytes in end-stage dilated cardiomyopathy patients ${ }^{23}$. As shown in chapter 3, Annexin imaging can detect apoptosis in dilated cardiomyopathy. We therefore hypothesize that Annexin A5 imaging of PS expression is 
a sensitive technique. Such sensitivity is needed when imaging small amounts of PS exposure, such as found in atherosclerosis. Chapter 2 shows feasibility of detecting unstable plaque in patients with symptomatic atherosclerotic carotid artery disease $\mathrm{e}^{24}$.

\section{ANNEXIN A5 IMAGING VERSUS OTHER MOLECULAR IMAGING TECHNIQUES}

Molecular imaging strategies have been around for quite some time, as the first scintillation camera was designed over 50 years ago by dr Anger at the Berkeley laboratory. Since those days a host of molecular targets have become available. Due to advances in genetics, bioinformatics and biotechnology, we now understand the biological basis of disease in greater detail. Recent advances in molecular imaging technology include monitoring of efficacy of stem cell therapy in cardiac repair using either magnetic resonance imaging $(\mathrm{MRI})^{25}$, positron emission tomography $(\mathrm{PET})^{26}$ or single photon emission computed tomography (SPECT) imaging. In addition, molecular imaging can be employed detecting effects of gene therapy and efficacy of transfection. The latter has been achieved among others by activatable imaging agents, where the imageable substrates are changed after interacting with their target ${ }^{27,28}$.

In atherosclerosis, numerous biological targets have been used for detection of plaque instability. These include imaging of matrix metalloproteinases (MMPs). MMPs are expressed in macrophages and endothelial cells, and are involved in atherosclerotic plaque disruption via enzymatic degradation of the fibrous cap. MMP imaging is feasible ${ }^{29}$, and may identify high risk atherosclerotic lesions. Activated macrophages are an attractive target for contrast agents. Detectable by PS exposure imaging, activated macrophages can also be identified by MRI, as these cells incorporate ultra small paramagnetic iron oxide particles (USPIO's) when activated ${ }^{30}$. PET FDG imaging has been used for detection of increased glucose metabolism in unstable atherosclerotic plaques. Prior studies have focused on imaging of atherosclerosis in patients undergoing PET FDG imaging for other indications, such as lung carcinoma ${ }^{31,32}$. Recent studies were carried out in patients with symptomatic carotid artery disease only, combining PET FDG and MRI imaging. Davies et al conducted a study in 12 patients with recent transient ischaemic attack (TIA), in which they show excellent correlation between FDG uptake and localization of TIA. In addition, PET FDG uptake co-localizes with atherosclerotic plaques with an unstable morphology on high resolution MRI (HRMRI) ${ }^{32}$. Obviously, carotid angiography detected site and severity of the carotid stenoses but was unable to identify the unstable plaques reliably. Of note, this is identical to the luminographic 
limitations of classical coronary angiography. Although the data are unconfirmed by immunohistochemical analysis of the endarterectomy specimen, there is a promising relation between PET uptake, HRMRI imaging and clinical symptoms ${ }^{32}$. Finally, recent publications have shown the use of PET FDG imaging in detecting plaque stabilization by statin treatment ${ }^{33}$, thus evaluating biological endpoints for success of treatment. Although PET FDG imaging is a very promising concept for carotid artery imaging, high background radiation due to myocardial uptake makes the compound less attractive for coronary imaging. HRMRI has the advantage of providing better image resolution than PET, CT or SPECT but is susceptible to motion artifacts. In addition, the sensitivity of MRI to targeted contrast agents is less then 1/1000 when compared to nuclear imaging techniques. Therefore, when imaging myocardial and epicardial disease, there is a need for a targeted nuclear imaging agent. Annexin A5 may be such an agent. In this thesis, we have shown feasibility of detection of unstable carotid plaque ${ }^{24}$. SPECT imaging theoretically has a higher spatial resolution then PET imaging. But, when applied clinically, PET is less susceptible to scatter by surrounding tissue. Applied clinically, PET provides images with a higher resolution due to the use of higher frequencies and radiation energy. In addition, quantification of activity of the molecular processes is possible only with PET. Future research will require fusion of the abovementioned technologies.

\section{FUTURE DIRECTIONS}

Annexin A5 has been labeled with positron emitting radionuclei, enabling PET imaging of PS exposure ${ }^{34,35}$. To date, no clinical studies have been performed. Developing a clinical PET Annexin A5 probe would enable detection of PS expression with higher sensitivity and resolution than SPECT imaging. In addition, PET is more easily quantifiable, aiding in evaluation of success of therapeutic interventions. We would like to suggest a clinical approach in which we identify high risk patients on the basis of classical risk factors combined with serological markers. Such patients could be referred for molecular imaging of high risk lesions. Once localized, these lesions could be imaged in detail by intravascular devices such as intravascular ultrasound using targeted contast agents, intravascular nuclear probes or intravascular OCT. These lesions could then be treated by percutaneous coronary interventional strategies and specific molecular therapies. Such an approach will need extensive clinical testing to validate the diagnostic and prognostic value of molecular imaging strategies, but holds the promise of preventive invasive therapy. 
In heart failure, molecular imaging of programmed cell death can identify patients that may benefit from cell death blocking strategies. In addition, cell death imaging technology can evaluate the success of cell death blocking strategies after acute myocardial infarction. The latter approach has been tried in animal models. Interestingly, our group has shown an effect on infarct size in mammals using the antibiotic minocycline as cell death blocking agent (unpublished data). Minocycline has been in use for many years as an antibiotic agent and has proven safe. As soon as a clinical imaging compound is available, this will be an exciting area to follow. Animal models have shown no deleterious side effects on function of "rescued" cardiomyocytes, but their clinical function in the course of many years will need to be evaluated.

Taken together, this thesis has shown feasibility and possible clinical applications of PS expression imaging. The studies performed are not large enough to evaluate statistical power, and clinical implementation will require further research. However, the results are promising and show proof of concept for clinical use of molecular imaging of programmed cell death. 


\section{REFERENCES}

1. Braunwald E. Epilogue: what do clinicians expect from imagers? J Am Coll Cardiol 2006; 47:C101-3.

2. Ridker PM, Cannon CP, Morrow D, et al. C-reactive protein levels and outcomes after statin therapy. N Engl J Med 2005; 352:20-8.

3. Ridker PM, Rifai N, Pfeffer MA, et al. Inflammation, pravastatin, and the risk of coronary events after myocardial infarction in patients with average cholesterol levels. Cholesterol and Recurrent Events (CARE) Investigators. Circulation 1998; 98:839-44.

4. van Kimmenade RR, Januzzi JL, Jr., Ellinor PT, et al. Utility of aminoterminal pro-brain natriuretic peptide, galectin-3, and apelin for the evaluation of patients with acute heart failure. J Am Coll Cardiol 2006; 48:1217-24.

5. Wang TJ, Gona P, Larson MG, et al. Multiple biomarkers for the prediction of first major cardiovascular events and death. N Engl J Med 2006; 355:2631-9.

6. Thimister PW, Hofstra L, Liem IH, et al. In vivo detection of cell death in the area at risk in acute myocardial infarction. J Nucl Med 2003; 44:391-6.

7. Hofstra L, Liem IH, Dumont EA, et al. Visualisation of cell death in vivo in patients with acute myocardial infarction. Lancet 2000; 356:209-12.

8. Kietselaer BL, Narula J, Hofstra L. The Annexin code: revealing endocarditis. Eur Heart J 2006.

9. Adams JW, Sakata Y, Davis MG, et al. Enhanced Galphaq signaling: a common pathway mediates cardiac hypertrophy and apoptotic heart failure. Proc Natl Acad Sci U S A 1998; 95:10140-5.

10. Sakata Y, Hoit BD, Liggett SB, Walsh RA, Dorn GW, 2nd. Decompensation of pressure-overload hypertrophy in $\mathrm{G}$ alpha q-overexpressing mice. Circulation 1998; 97:1488-95.

11. Hayakawa $Y$, Chandra M, Miao W, et al. Inhibition of cardiac myocyte apoptosis improves cardiac function and abolishes mortality in the peripartum cardiomyopathy of Galpha(q) transgenic mice. Circulation 2003; 108:3036-41.

12. Hirota $H$, Yoshida K, Kishimoto $T$, Taga T. Continuous activation of gp130, a signal-transducing receptor component for interleukin 6related cytokines, causes myocardial hypertrophy in mice. Proc Natl Acad Sci U S A 1995; 92:4862-6.

13. Hirota $\mathrm{H}$, Chen J, Betz UA, et al. Loss of a gp130 cardiac muscle cell survival pathway is a critical event in the onset of heart failure during biomechanical stress. Cell 1999; 97:189-98.

14. De Windt LJ, Lim HW, Taigen T, et al. Calcineurin-mediated hypertrophy protects cardiomyocytes from apoptosis in vitro and in vivo: An apoptosis-independent model of dilated heart failure. Circ Res 2000; 86:255-63. 
15. Narula J, Haider N, Virmani R, et al. Apoptosis in myocytes in end-stage heart failure. N Engl J Med 1996; 335:1182-9.

16. Narula J, Pandey P, Arbustini E, et al. Apoptosis in heart failure: release of cytochrome c from mitochondria and activation of caspase-3 in human cardiomyopathy. Proc Natl Acad Sci U S A 1999; 96:8144-9.

17. Scheubel RJ, Bartling B, Simm A, et al. Apoptotic pathway activation from mitochondria and death receptors without caspase-3 cleavage in failing human myocardium. Fragile balance of myocyte survival? J Am Coll Cardiol 2002; 39:481-8.

18. Haider N, Narula N, Narula J. Apoptosis in heart failure represents programmed cell survival, not death, of cardiomyocytes and likelihood of reverse remodeling. J Card Fail 2002; 8:S512-7.

19. Narula N, Narula J, Zhang PJ, et al. Is the myofibrillarlytic myocyte a forme fruste apoptotic myocyte? Ann Thorac Surg 2005; 79:1333-7; discussion 1337.

20. Chandrashekhar Y, Narula J. Death hath a thousand doors to let out life. Circ Res 2003; 92:710-4.

21. van Empel VP, Bertrand AT, van der Nagel R, et al. Downregulation of apoptosis-inducing factor in harlequin mutant mice sensitizes the myocardium to oxidative stress-related cell death and pressure overloadinduced decompensation. Circ Res 2005; 96:e92-e101.

22. van Empel VP, Bertrand AT, van Oort RJ, et al. EUK-8, a superoxide dismutase and catalase mimetic, reduces cardiac oxidative stress and ameliorates pressure overload-induced heart failure in the harlequin mouse mutant. J Am Coll Cardiol 2006; 48:824-32.

23. Olivetti G, Abbi R, Quaini F, et al. Apoptosis in the failing human heart. N Engl J Med 1997; 336:1131-41.

24. Kietselaer BL, Reutelingsperger CP, Heidendal GA, et al. Noninvasive detection of plaque instability with use of radiolabeled annexin A5 in patients with carotid-artery atherosclerosis. N Engl J Med 2004; 350:1472-3.

25. Hill JM, Dick AJ, Raman VK, et al. Serial cardiac magnetic resonance imaging of injected mesenchymal stem cells. Circulation 2003; 108:100914.

26. Amado LC, Saliaris AP, Schuleri KH, et al. Cardiac repair with intramyocardial injection of allogeneic mesenchymal stem cells after myocardial infarction. Proc Natl Acad Sci U S A 2005; 102:11474-9.

27. Louie AY, Huber MM, Ahrens ET, et al. In vivo visualization of gene expression using magnetic resonance imaging. Nat Biotechnol 2000; 18:321-5.

28. Weissleder R, Moore A, Mahmood U, et al. In vivo magnetic resonance imaging of transgene expression. Nat Med 2000; 6:351-5. 
29. Bremer $\mathrm{C}$, Tung $\mathrm{CH}$, Weissleder R. Molecular imaging of MMP expression and therapeutic MMP inhibition. Acad Radiol 2002; 9 Suppl 2:S3145.

30. Kooi ME, Cappendijk VC, Cleutjens KB, et al. Accumulation of ultrasmall superparamagnetic particles of iron oxide in human atherosclerotic plaques can be detected by in vivo magnetic resonance imaging. Circulation 2003; 107:2453-8.

31. Tatsumi M, Cohade C, Nakamoto Y, Wahl RL. Fluorodeoxyglucose uptake in the aortic wall at PET/CT: possible finding for active atherosclerosis. Radiology 2003; 229:831-7.

32. Davies JR, Rudd JH, Fryer TD, et al. Identification of culprit lesions after transient ischemic attack by combined $18 \mathrm{~F}$ fluorodeoxyglucose positron-emission tomography and high-resolution magnetic resonance imaging. Stroke 2005; 36:2642-7.

33. Tahara $N$, Kai $H$, Ishibashi $M$, et al. Simvastatin attenuates plaque inflammation: evaluation by fluorodeoxyglucose positron emission tomography. J Am Coll Cardiol 2006; 48:1825-31.

34. Yagle KJ, Eary JF, Tait JF, et al. Evaluation of 18F-annexin V as a PET imaging agent in an animal model of apoptosis. J Nucl Med 2005; 46:658-66.

35. Keen HG, Dekker BA, Disley L, et al. Imaging apoptosis in vivo using 124I-annexin V and PET. Nucl Med Biol 2005; 32:395-402. 
CHAPTER 7

Summary 
82 CHAPTER 7 
Despite advances in clinical medicine and medical technology, cardiovascular disease remains the leading cause for morbidity and mortality in developed countries. A large number of these patients present themselves to clinicians only after substantial damage has been caused by cardiovascular disease. Examples of this are patients presenting with myocardial infarction or in a late stage of congestive heart failure. Previously we accepted such cases as a natural and unavoidable manifestation of disease. Presently it is clear that many of tehse patients suffer from subclinical disease. Most of these patients have one or more classical or new risk factors. Classical risk factors may identify high risk patients, and additional testing of several serum markers may add to further risk stratification. However, such risk stratification is unable to predict timing of clinical cardiovascular events.

Cardiovascular events such as congestive heart failure, myocardial- and cerebral are preceded by specific biological changes. Molecular imaging is a novel imaging technology allowing detection of such subclinical biological changes. Physicians strive to prevent organ damage and functional deterioration in patients. Hence, there is an unmet clinical need for technology detecting pre-clinical molecular changes, and pre-clinical disease states. This thesis focuses on employing radiolabeled Annexin A5 for the detection of PS expression in patients suffering from (pre-) clinical cardiovascular disease. We hypothesized that detection of PS expression in patients may identify high risk individuals. Such individuals may benefit from aggressive treatment. PS expression is a hallmark of apoptosis, but can also been found in activated macrophages and activated blood platelets.

This thesis shows feasibility of detection of PS expression in patients suffering from dilated cardiomyopathy. PS expression in these patients is most likely due to apoptosis. In patients with uptake of radiolabeled Annexin A5 in the area of the heart the LV function deteriorated, and functional class deteriorated. In contrast, patients without non-invasive evidence of PS expression remained clinically stable. In this group, left ventricular function improved slightly over time.

Furthermore, we have shown the use of Annexin A5 imaging in detection of inflammation. Chapter 3 shows the use of radiolabeled Annexin A5 in detection of infective endocarditis prior to blood cultures becoming positive. Chapter 4 describes the use of Annexin A5 imaging in detection of unstable plaque in carotid arteries of patients that have suffered a transient ischaemic attack (TIA) or minor stroke. Such patient will benefit from surgical therapy.

Finally, this thesis shows the use of molecular imaging with Annexin A5 in patients with an unknown intracardiac mass. Intracardiac masses are un- 
suitable for biopsy taking due to the high risk of embolic complications. Thus, making a diagnosis prior to surgery is often difficult. However, surgical approach may vary significantly when addressing either a benign or malignant intracardiac mass. We have shown the use of radiolabeled Annexin A5 in making a diagnosis prior to surgical intervention. Chapter 6 shows the cohort of patients with an unknown intracardiac mass. In the cases with a negative scan, no malignant tumors were found. Follow-up of 5 years showed an excellent prognosis. Positive scans were associated with malignant tumor or infective endocarditis.

These date show that molecular imaging can detect biological changes preceding disease. More precisely, this thesis shows feasibility of molecular imaging using radiolabeled Annexin A5 for detection of PS expression in patients suffering from a wide variety of cardiovascular disease. Annexin imaging was able to detect high risk patients developing heart failure, infective endocarditis and TIA or stroke. Furthermore, Annexin imaging aided in making a diagnosis in patients with tumors unsuitable for biopsy taking. Such patients are candidates for aggressive, novel treatment. In risk stratifying patients, molecular imaging may improve prognosis in high risk patients by enabling prevention of end-organ damage. Additionally, molecular imaging may be used in evaluating success of novel treatment strategies as biological effects can be monitored real time, repeatedly. The ultimate goal would be to employ insights gained by molecular imaging for early, individualized treatment. 
CHAPTER 8

Nederlandstalige samenvatting 
86 CHAPTER 8 


\section{THE ANNEXIN CODE: REVEALING CARDIOVASCULAR DISEASE}

Ondanks de vorderingen in medische kennis en technologie, blijven cardiovasculaire ziekten de meest belangrijke oorzaak voor mortaliteit en morbiditeit in de westerse wereld. Een groot gedeelte van de patiënten komen pas onder de aandacht van de medische wereld nadat een cardiovasculaire ziekte al uitgebreide schade heeft aangericht. Dit is het geval bij patiënten die zich presenteren met een myocardinfarct of in een laat stadium van hartfalen. In het verleden werden dergelijke casus geaccepteerd als een natuurlijke en niet te voorkomen manifestatie van cardiovasculair lijden. Tegenwoordig is duidelijk dat vele van deze patiënten al subklinische ziekte hebben. De meeste van deze mensen hebben één of meer klassieke of nieuwe risicofactoren. Risicofactoren kunnen hoog risicopatiënten identificeren, en bloedonderzoek kan eventueel nog iets bijdragen aan verdere risicostratificatie. Echter, deze manier van risicostratificatie kan de timing van cardiovasculaire events zoals een hart- of herseninfarct niet voorspellen.

Cardiovasculaire events zoals hartfalen, hart- en herseninfarcten worden voorafgegaan door specifieke biologische veranderingen. Moleculaire beeldvorming is een nieuwe beeldvormende techniek welke in staat is dergelijke subklinische biologische veranderingen waar te nemen. Artsen willen weefselschade en achteruitgang in functioneren bij patiënten voorkomen. Daarom is er een vraag naar technologie die zulke biologische veranderingen detecteert. Deze promotie focust op het gebruik van gelabeld Annexine A5 voor de detectie van PS expressie in patiënten. PS expressie wordt gezien bij geprogrammeerde celdood en macrofaag- en plaatjesactivatie. De onderzoekshypothese van dit proefschrift is dat detectie van PS expressie helpt bij identificatie van hoogrisico patiënten.

Dit proefschrift toont dat PS expressie detectie mogelijk is bij patiënten met een gedilateerde cardiomyopathie (DCM). PS expressie is in dit geval een teken van apoptose. Het is in eerdere studies aangetoond dat apoptose in een belangrijke mate bijdraagt aan achteruitgang van de functie van het hart bij patiënten met een gedilateerde cardiomyopathie. Voor die eerdere studies was het echter steeds nodig biopten te nemen van de hartspier. In dit proefschrift laten we zien dat door middel van Annexine A5 scans noninvasief PS expressie aangetoond kan worden bij patiënten met DCM. De scan lijkt eveneens een voorspellende waarde te hebben: bij patiënten met een positieve Annexine A5 scan werd de cardiale functie slechter, en nam de algehele conditie af. De cardiale functie en conditie bleef stabiel bij mensen met een negatieve scan. 
Daarnaast werd de Annexine scan gebruikt voor detectie van ontsteking. Bij patiënten met de verdenking op een bacteriële ontsteking van het hart, endocarditis genaamd, is het belangrijk snel een diagnose te hebben. Als behandeling te laat gestart wordt kan een endocarditis veel schade aan de hartspier en -kleppen aanrichten, welke vaak maar moeizaam te herstellen is. Hoofdstuk 3 laat zien dat Annexine scans endocarditis kunnen detecteren voordat bloedkweken positief worden, en zo kan helpen in de vroege diagnostiek van endocarditis.

Ontsteking, celdood en plaatjesactivatie worden allemaal gezien bij "slagaderverkalking", of atherosclerose. Acute ziekten van hart en bloedvaten zoals infarcten worden vaak niet veroorzaakt door langzaam progressieve vernauwing van een bloedvat, maar door vorming van een stolsel dat een bloedvat afsluit. De plaatsen waar zulk een stolsel ontstaat worden wel "kwetsbare plaques" genoemd. In hoofdstuk 4 laten we zien dat Annexine scans gebruikt kunnen worden voor aantonen van kwetsbare atherosclerotische plaques bij patiënten met een TIA ("lichte beroerte"). Het is de hoop dat dergelijke scans hersen- en hartinfarcten kunnen zien aankomen, zodat ze in de toekomst voorkomen kunnen worden.

Tenslotte laat dit proefschrift zien dat Annexine scans gebruikt kunnen worden bij patiënten met een massa in het hart. Omdat er geen biopten van een intracardiale massa genomen kunnen worden, is vaak onduidelijk of het om een goed- of kwaadaardig gezwel gaat. Patiënten met een positieve scan hadden ofwel een maligne tumor, ofwel actieve endocarditis of een vers trombus. Patiënten met een negatieve scan hadden een goedaardig gezwel. 5 Jaar follow-up liet zien dat patiënten met een negatieve scan een uitstekende prognose hadden.

Deze data laten zien dat moleculaire beeldvorming biologische veranderingen kan detecteren welke voorafgaan aan klinische ziekten. Waarschijnlijk kunnen hoog-risico patiënten geïdentificeerd worden, gebruik makend van met moleculaire beeldvorming. Een dergelijke patiënt kan dan agressiever behandeld worden met conventionele of nieuwe technieken. Daarnaast kan moleculaire imaging gebruikt worden om het succes van dergelijke behandeling te evalueren. Het doel is dat met inzichten verkregen door moleculaire imaging vroege, geïndividualiseerde behandeling van patiënten verwezenlijkt kan worden. 
Full color figures 


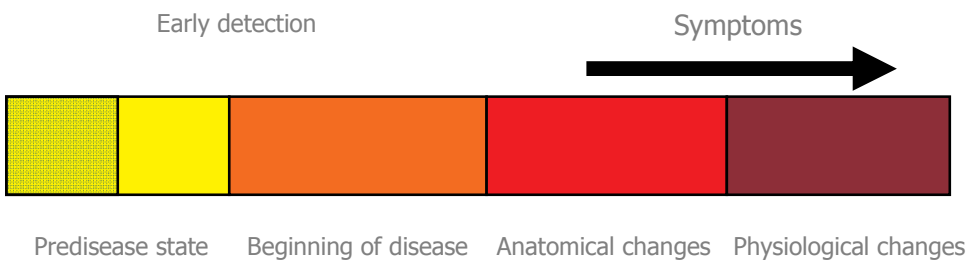

Chapter 1, Figure 1:

Molecular imaging versus anatomical imaging. Molecular imaging detects changes on a molecular level, preceding the changes in anatomy. Potentially, detecting disease in an early stage may aid clinicians and patients, enabling early treatment. In addition, scans can be easily repeated studying effect of treatment. Furthermore, information on lesions not suitable for biopsy taking can be acquired.
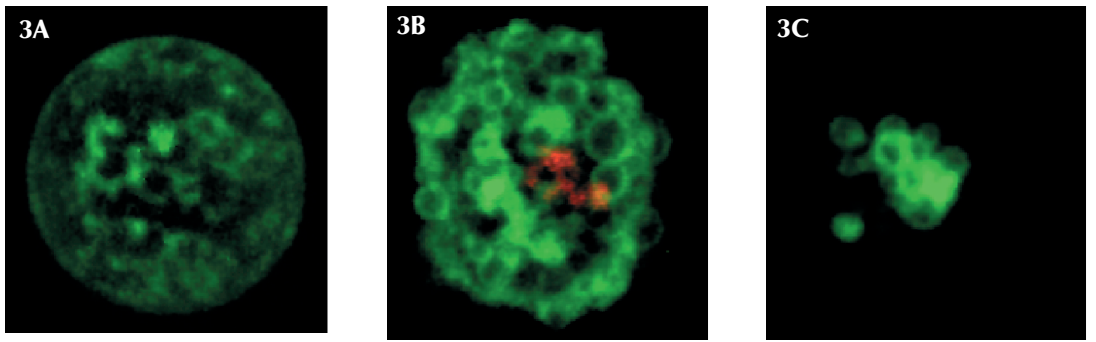

Chapter 1, Figure 3:

Annexin A5 binds to cells in all stages of the cell death program. Here, Jurkat cells are stimulated by Fas ligand. In figure $3 A$, the early phase of apoptosis is seen. Already we can observe binding of fluorescent labeled Annexin $A 5$ to the cell membrane. Figure $3 B$ depicts a later stage, in which we see formation of blebs and Annexin A5 binding. Figure 3C is the final stage of apoptosis, the cell remnants. These also bind labeled Annexin A5. 


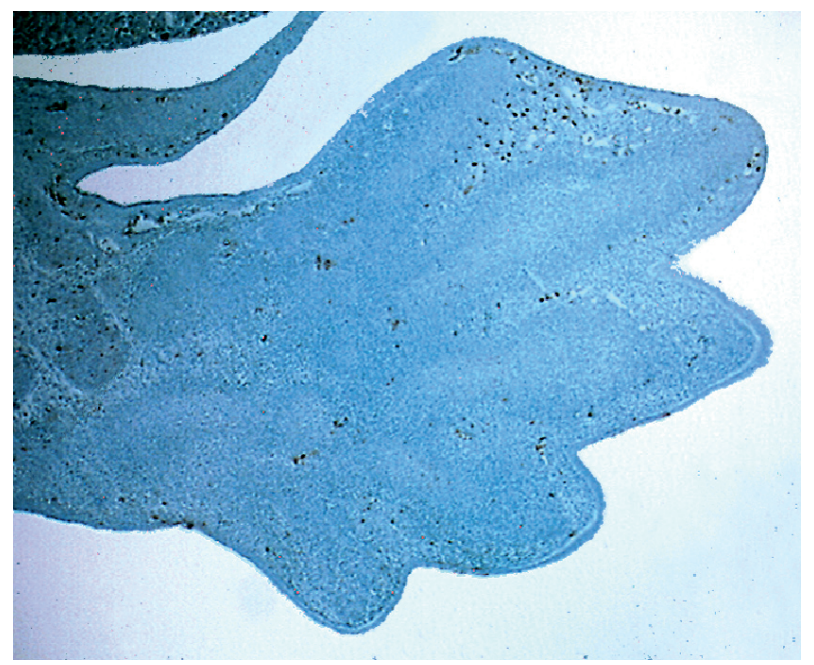

Chapter 1, Figure 4:

Paw of a chick embryo at day 13. Binding of labeled Annexin A5 (note brown staining) can de observed in interdigit spaces
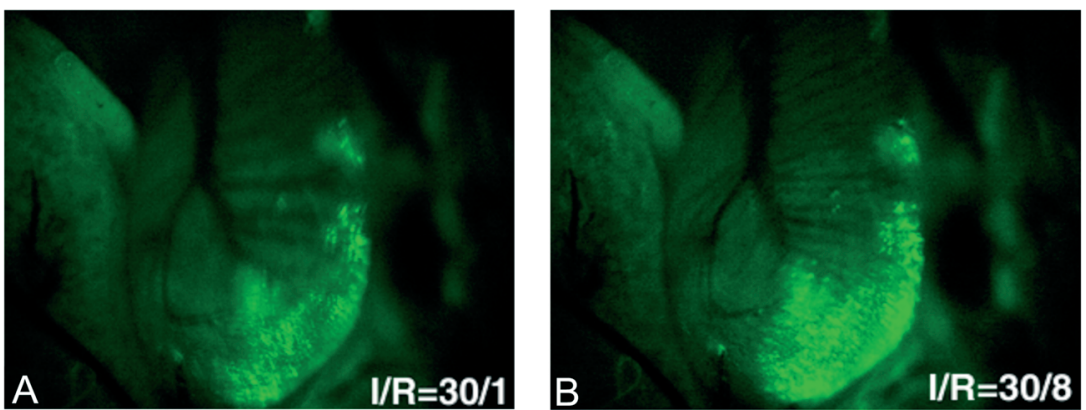

Figure 5:

In-vivo whole heart imaging of mice undergoing ischaemia (I) and reperfusion ( $R$ ). Images taken after 30 minutes of ischaemia and 1 and 8 minutes of reperfusion, respectively. Annexin A5 has been labeled with a green fluorescent molecule. Notice the increase in intensity of signal. Via this method, the externalization of PS can be monitored in a time dependent manner, allowing real time visualization of activation of the cell death program in the beating heart. For full color image see page 92. 


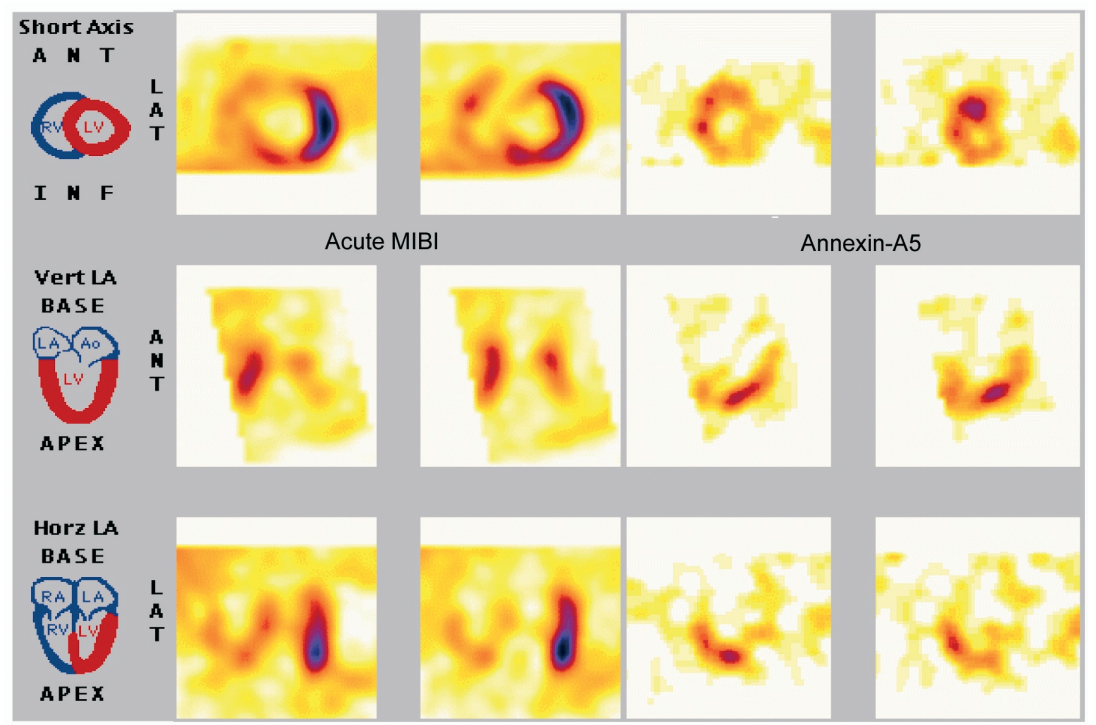

Chapter 1, Figure 6:

Detection of cell death in a patient with acute myocardial infarction, using technetium labeled Annexin A5. The left panel shows perfusion imaging in the acute stage prior to opening of the occluded artery. The perfusion defect is used as a measure of the area at risk. The right panel shows imaging of the binding of technetium labeled Annexin A5 within the area at risk, indicating presence of programmed cell death in the area of infarction. 

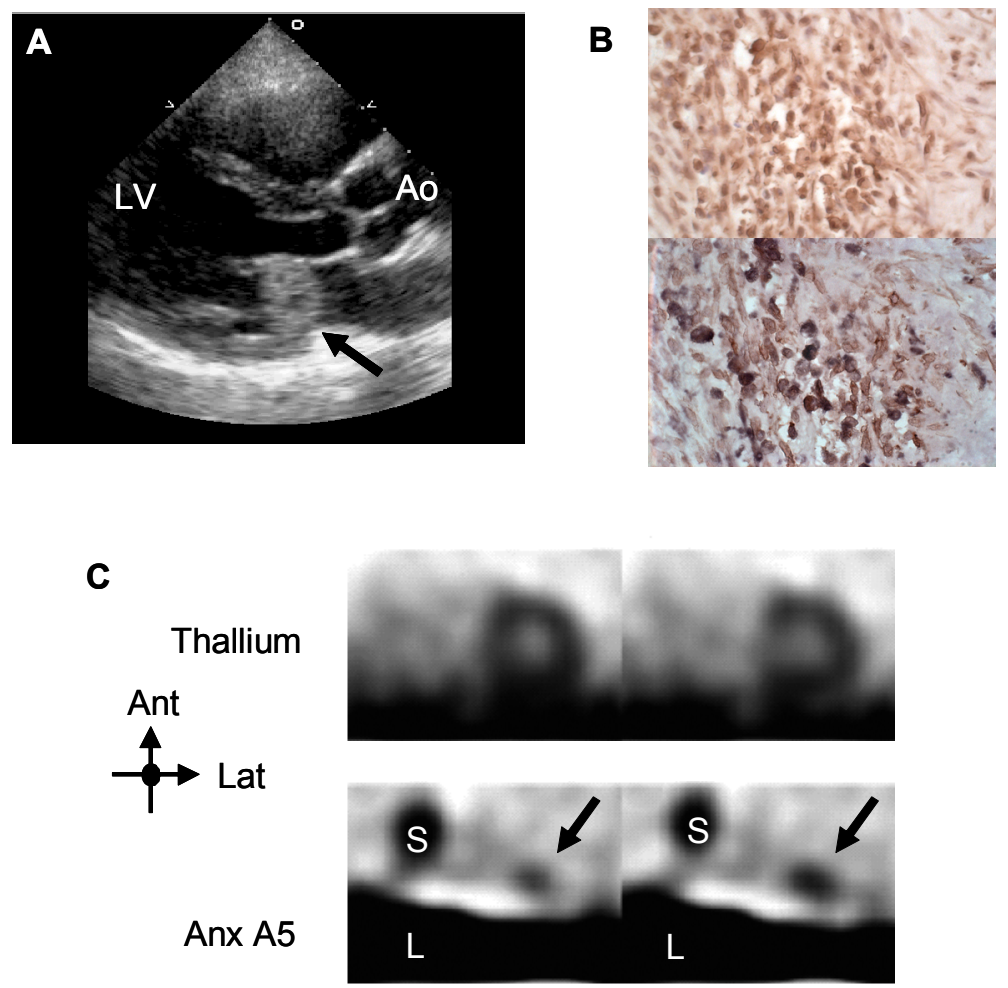

Chapter 3, Figure 1:

A: Transthoracal echocardiography, parasternal long axis view of the left ventricle. Arrowhead depicts mass attached to the mitral valve. Ao = Aorta; $L V=$ Left ventricle. $B$ : Immunohistochemistry of the intracardiac mass. Brown staining = Annexin A5. Upper panel shows extensive binding of Annexin A5 to cell membranes. Lower panel shows co-localisation of a macrophage marker (CD68, dark blue staining), and Annexin A5. C: Dual isotope imaging using ${ }^{201} T L$ and ${ }^{99 m} T C$ Annexin A5. Arrowheads point to Annexin A5 uptake in the area of the mitral valve. 
Recent TIA

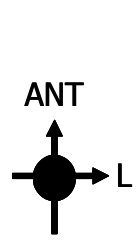

A

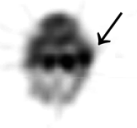

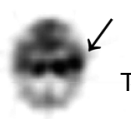

Transverse

3 month old TIA

C
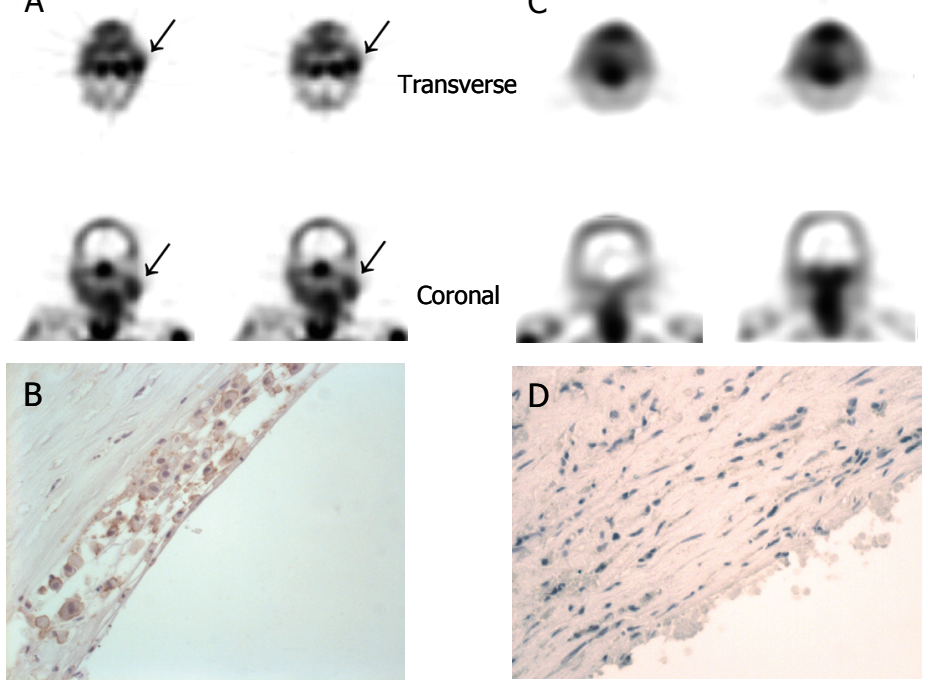

Chapter 4, Figure 1:

Annexin A5 imaging of carotid artery atherosclerosis. Panel A: Annexin imaging in a patient with recent TIA. Note enhanced uptake in the left carotid artery region (arrowheads). Panel B: Unstable atherosclerotic plaque and Annexin binding to cell membranes, mainly macrophages. Panel C: Annexin imaging in remote TIA, no enhanced uptake is observed. Panel D: Stable atherosclerotic plaque, absence of Annexin A5 binding to cells. 

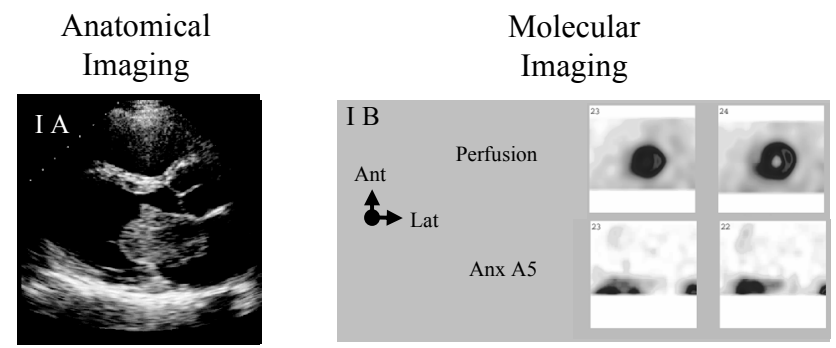

Histology
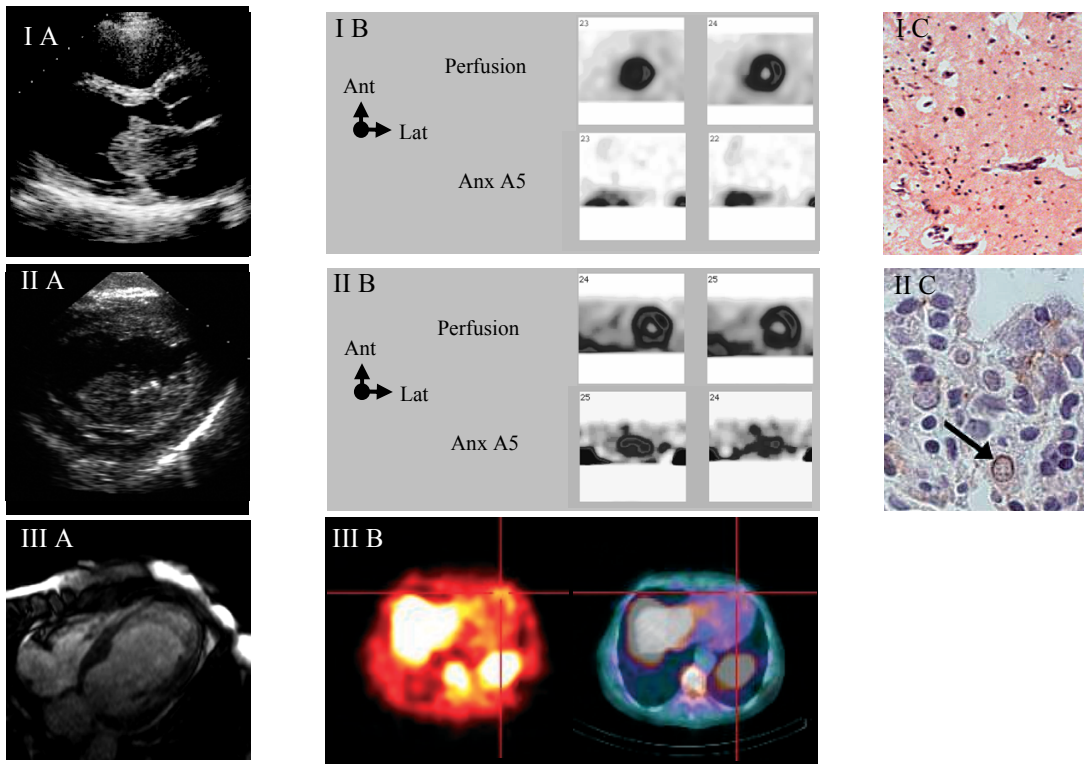

Chapter 5, Figure 1:

Molecular and anatomical imaging of intracardiac masses.

Panel IA shows a parasternal long axis view of the left ventricle. There is a clear intracardiac mass shown in the area of the mitral valve. Panel IB shows a normal perfusion image of the left ventricle (short axis view). Note the absence of uptake of annexin A5 in the same region. Panel IC shows histology, no Annexin A5 staining was observerd.

Panel IIA shows a parasternal long axis view of the left ventricle with a large mass attached to the left ventricular wall. Panel IIB shows intense uptake of radiolabeled Annexin A5 in the region of the left ventricle. Panel IIC confirms binding of annexin A5 to cells (brown staining). Histology showed sarcoma

Panel IIIA is a cardiac magnetic resonance image. This four chamber view shows a large mass attached to the LV apex in the presence of an apical infarct. Panel IIIB shows uptake of radiolabeled Annexin in the area of the LV apex in the left panel. Right panel shows a fusion image between low resolution CT and nuclear imaging, confirming the localization of the Annexin uptake (LV apex). In this case no cardiac surgery was performed. 
Dankwoord 
Het schrijven van een proefschrift is allerminst een solo prestatie. Ook in mijn geval was het tot een goed einde brengen van mijn proefschrift alleen mogelijk met de hulp van een groot aantal mensen. De teamgeest die ik heb mogen ervaren tijdens het doen van dit onderzoek was fantastisch.

Speciale dank gaat uit naar de mensen van het "Annexine-team". Rond Leo Hofstra en Chris Reutelingsperger heeft zich een heel team van Annexinefans verzameld. Leo, jij als directe begeleider hebt me wegwijs gemaakt in de wondere wereld van de wetenschap. Als ik iets van je heb mogen leren dan is het je eeuwige optimisme, en de manier waarop je van iedere tegenslag weer een mogelijkheid tot nieuwe ontdekkingen maakte. Gelukkig was er altijd ruimte voor humor. Ik kan me nog de tekeningen herinneren bij mijn artikelen. Rookwolkjes en "Bas, verhalen voor bij het haardvuur" als ik weer eens te lang van stof was. Bedankt voor een schitterende tijd, zowel wetenschappelijk als tijdens extra-curriculaire activiteiten. Op de squashbaan en tijdens hardlopen was je me de baas, misschien is er nu tijd om te trainen en revanche te nemen. Chris, je was een enorm waardevol aanspreekpunt bij al mijn biochemische problemen. Dank voor de "hardcore science" ondersteuning aan deze jonge arts.

Promotor prof. dr. H.J.G.M. Crijns, U hebt mij vooral tijdens het laatste deel van mijn promotietraject weten aan te zetten tot daadwerkelijk schrijfwerk. Het was soms lastig de klinische taken te combineren met het afronden van het proefschrift. Mijn gesprekken met u en het inhoudelijk commentaar op de stukken hebben de wetenschappelijk interesse weten te behouden tijdens mijn jaren in de periferie. Dank!

Professor Narula, dear Jagat. I am grateful for the fruitful discussions we had about science. I enjoyed the brief time I had the opportunity to stay at you lab in Irvine. The "Indian hospitality" was amazing. I look forward to meeting you again in the future. Your enthousiasm for science is contagious. It has inspired me and many of my colleagues.

Professor dr. G.A.K. Heidendal, u en uw team hebben mij wegwijs gemaakt op de afdeling nucleaire geneeskunde. Ik heb mij altijd een welkome gast gevoeld. Dank voor de bereidheid alle nieuwe zaken met u te bespreken. Uw relativerende woorden als ons enthousiasme weer eens met ons op de loop ging heb ik altijd als positief ervaren. Daarnaast natuurlijk mijn dank aan de laboranten van de nucleaire geneeskunde. Het geduld van MarieTherese Pakbiers, Serve Halders en Denise Janssen kende geen grenzen. Altijd waren jullie bereid alle data nog eens voor mij op een rij te zetten, me te helpen met uitwerken van scans en de bediening van de apparatuur. Ik voel me heel wat veiliger in een hotlab dankzij jullie en jullie collega's. 
Professor. dr. G.J.J. Teule, natuurlijk ook dank voor uw gastvrijheid en wetenschappelijke geest.

Mijn directe collega's hebben in belangrijke mate bijgedragen aan het plezier in het werk. Ewald Dumont, bedankt voor je inwijding in de fijne kneepjes van de immuunhistochemie en begeleiding bij mijn eerste stappen op dit lange Annexine pad. We zullen elkaar vast nog wel tegenkomen tijdens onze onderzoeksactiviteiten. Abdel, dank voor je gezelligheid en hulp bij atherosclerose papers. Nicole, bedankt voor de hulp bij het scheppen van orde in de soms chaotische administratie van de coupe's. Johan, jouw enthousiasme voor onderzoek en alle leuke dingen er omheen hebben altijd voor een goed humeur bij mij gezorgd. Altijd ben je bereid weer een paper op te diepen over een obscuur onderwerp, om daarna een en ander af te ronden met een partijtje weergaloos hockey. Tot op het veld! Sander, Maarten, Heidi, Eva, Vanessa, Veerle, Suzanne en Ward, bedankt voor alle hulp.

$\mathrm{Pa}$, ma en Suzanne, fijn dat jullie zijn blijven vertrouwen in mijn promotietraject. Jullie zijn er altijd van uitgegaan dat dit proefschrift tot een goed einde gebracht ging worden, ook toen dat einde even op zich liet wachten.

Lieve Isa, ik heb je halverwege mijn onderzoekstraject leren kennen tijdens een carnavalsavondje uit met de cardiologie. De Annexine club was al uitstekend aan je geïntroduceerd door Chris (dankjewel), en 5 jaar later ben ik de gelukkige die straks met je mag trouwen. Jouw doorzettingsvermogen en eindeloos geduld met mijn schrijfwerk hebben veel voor mij betekend. Je steun tijdens de afrondende fase van dit proefschrift heeft ervoor gezorgd dat het uiteindelijk zover heeft mogen komen. 
Curriculum vitae 
Bas Kietselaer werd geboren in Nijmegen in 1976. Hij groeide op in Doetinchem, waar hij in 1994 zijn VWO diploma haalde op het St Ludgercollege. Hij deed zijn studie geneeskunde aan de universiteit Maastricht, waar hij in 2001 zijn basisartsdiploma behaalde. Gedurende zijn studie en zijn coschappen verdiepte hij zich in de cardiologie middels keuze-onderwijs en wetenschappelijk onderzoek naar boezemfibrilleren bij dr J.L.R.M. Smeets. In maart 2001 startte hij met zijn baan als arts-assistent cardiologie. Kort daarna in oktober 2001 werd hij aangesteld als clinical fellow cardiologie en deed zijn wetenschappelijk onderzoek onder begeleiding van dr. L. Hofstra. De resultaten heeft u kunnen lezen in dit proefschrift. Vanaf januari 2006 is hij werkzaam als cardioloog in opleiding in het academisch ziekenhuis Maastricht met speciale aandacht voor de non-invasieve beeldvorming

Bas Kietselaer was born in Nijmegen in 1976. He grew up in Doetinchem where he received his secondary education at the St. Ludgercollege. In 1994 he enrolled in his medical studies at the university of Maastricht. He obtained his MSc degree in 1998 and his medical degree in 2001.During his medical studies and internships he broadened his knowledge of cardiology by elective programs. In addition he participated in medical research guided by dr J.L.R.M. Smeets. In march of 2001 he started his residency in cardiology at the University Hospital of Maastricht. In oktober of 2001 he was appointed as a clinical fellow of cardiology. During this period he performed the studies under dr. L. Hofstra, leading up to this thesis. From January 2006 the author works as a resident of cardiology in the university hospital of Maastricht. 
List of publications 
Molecular imaging of cell death in intra-cardiac tumors;A new approach to differential diagnosis in cardiac tumors.

B.L.J.H. Kietselaer MD; P.W.L. Thimister MD, PhD; C.P.M. Reutelingsperger PhD; G.A.K. Heidendal MD, PhD; E.A.W.J. Dumont MD; H.H. Boersma PharD; L Hofstra MD, PhD

Netherlands Heart Journal, 2002; 10: pp. 313-7

Non-invasive detection of plaque instability using radiolabeled Annexin-A5 in patients with atherosclerotic carotid artery disease.

Bas L.J.H. Kietselaer MD; Chris P.M. Reutelingsperger PhD; Guido A.K. Heidendal MD, PhD; Werner H. Mess MD, PhD; Mat J.A.P. Daemen MD, PhD; Leo Hofstra MD, PhD and Jagat Narula MD, PhD.

New England Journal of Medicine 2004, April 1, 364, pp 1124-5

Molecular Imaging of Programmed Cell Death; from basic mechanisms to clinical applications.

Bas L.J.H. Kietselaer, Chris P.M. Reutelingsperger, Leonard Hofstra

Chapter in: Cell engineering volume 4: apoptosis

Editor: Prof Al Rubeai, Kluwer Academic Publishers

Imaging of Apoptotic Cell Death in Myocardial Disease

Chris Reutelingsperger, Bas Kietselaer, Jagat Narula, H William Strauss, Leo Hofstra

Chapter in: The Future of Nuclear Cardiology

Kluwer Academic Publishers

The role of labeled Annexin A5 in imaging of programmed cell death: from animal to clinical imaging.

B.L.J.H. Kietselaer, MD; L. Hofstra. MD, PhD; E.A.W.J. Dumont, MD; C.P.M. Reutelingsperger, PhD; G.A.K. Heidendal, MD, PhD.

Quarterly Journal of Nuclear Medicine, 2003 Dec;47(4):349-61.

The Annexin code: revealing endocarditis

B.L.J.H. Kietselaer, MD; J. Narula, MD, PhD; L. Hofstra, MD, PhD

Eur Heart J. 2007 Apr;28(8):948. Epub 2006 Nov 3.

Selective endothelin B receptor blockade does not influence BNP-induced natriuresis in man.

van der Zander K, Houben AJ, Webb DJ, Udo E, Kietselaer B, Hofstra L, De Mey JG, de Leeuw PW.

Kidney Int. 2006 Mar;69(5):864-8. 
Past, present, and future of annexin A5: from protein discovery to clinical applications.

Boersma HH, Kietselaer BL, Stolk LM, Bennaghmouch A, Hofstra L, Narula J, Heidendal GA, Reutelingsperger CP.

Journal of Nuclear Medicine, 2005 Dec;46(12):2035-50. Review.

ACST: which subgroups will benefit most from carotid endarterectomy?

Kietselaer BL, Hofstra L, Narula J.

Lancet. 2004 Sep 25-Oct 1;364(9440):1124-5; author reply 1125-6.

Role of molecular imaging in defining and denying death...

Narula J, Kietselaer B, Hofstra L.

J Nucl Cardiol. 2004 May-Jun;11(3):349-57.

Noninvasive detection of programmed cell loss with 99mTc-labeled annexin A5 in heart failure.

Bas L.J.H. Kietselaer, MD; Chris P.M. Reutelinsperger, PhD; Hendrikus Boersma, PharmD; Guido A.K. Heidendal, MD, PhD; Ing An Liem, MD; Hein J.J. Wellens, MD, PhD'; Leo Hofstra, MD, PhD; J. Narula, MD, PhD

Journal of Nuclear Medicine, 2007 Apr;48(4):562-7

Submitted:

${ }^{99 m}$ Tc-labeled Annexin A5 imaging of intracardiac space occupying lesions: Feasibility of dichotomous diagnosis of risky masses.

B.L.J.H. Kietselaer, MD; M.J.M. Cramer, MD, PhD; J. Narula, MD, PhD; N. Narula MD, PhD; I.H. Liem, MD; H.H. Boersma, PharD; M. Pakbiers, C.P.M. Reutelingsperger, PhD; G.A.K. Heidendal MD, PhD; H.J.J. Wellens MD, PhD, H. Crijns MD, PhD; L. Hofstra MD, PhD. 